\title{
Long Duration Testing of Type C Thermocouples at $1500{ }^{\circ} \mathrm{C}$
}

\author{
J. L. Rempe \\ D. L. Knudson \\ J. E. Daw \\ S. C. Wilkins
}

April 2008

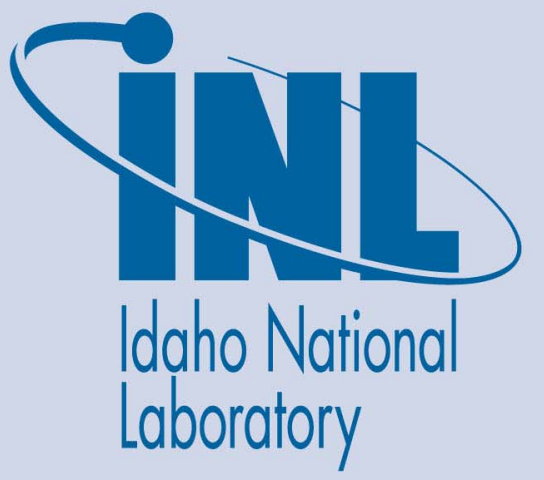

The INL is a U.S. Department of Energy National Laboratory operated by Battelle Energy Alliance 
INL/EXT-07-13531

Rev. 1

\title{
Long Duration Testing of Type C Thermocouples at $1500^{\circ} \mathrm{C}$
}

\author{
J. L. Rempe \\ D. L. Knudson \\ J. E. Daw \\ S. C. Wilkins
}

April 2008

\section{Idaho National Laboratory \\ Idaho Falls, Idaho 83415}

Prepared for the

U.S. Department of Energy

Through the INL LDRD Program

Under DOE Idaho Operations Office

Contract DE-AC07-05ID14517 


\section{CONTENTS}

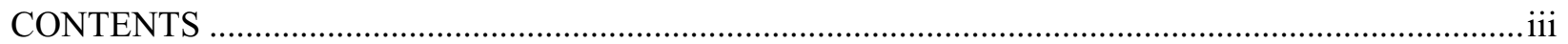

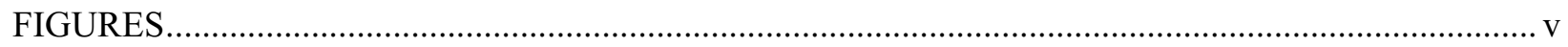

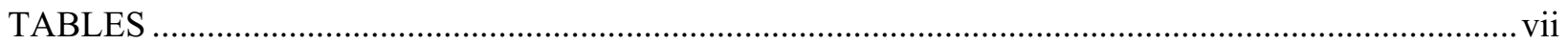

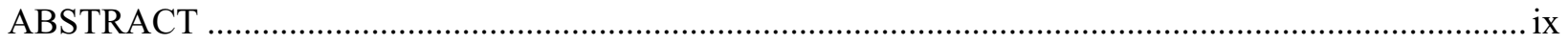

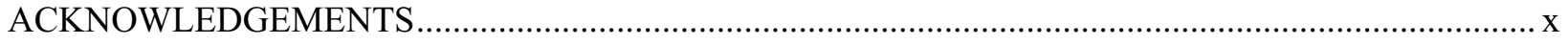

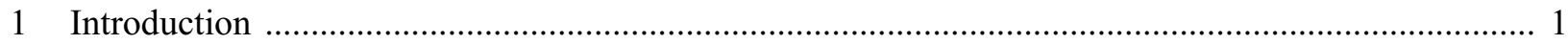

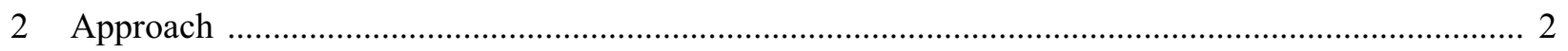

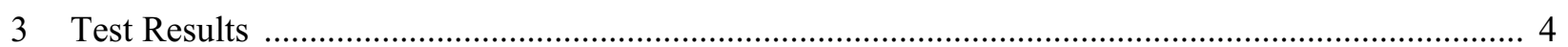

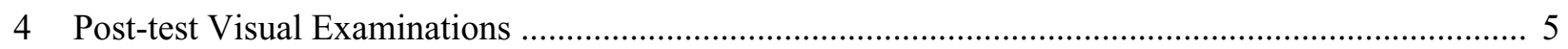

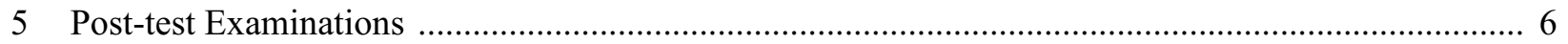

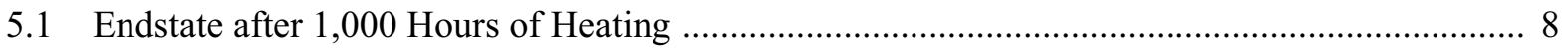

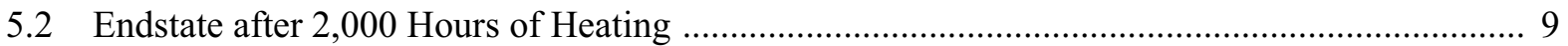

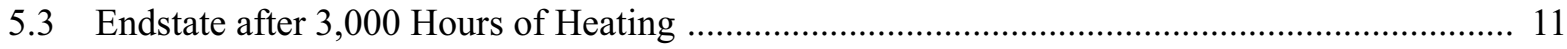

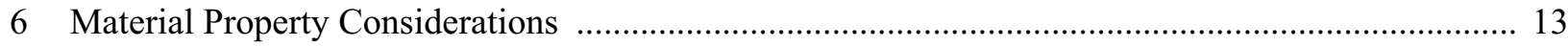

7 Summary and Recommendations for Future Evaluations ...................................................... 15

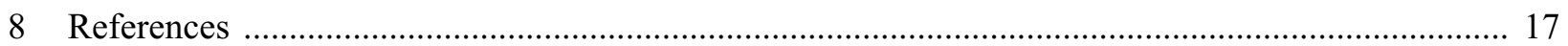




\section{FIGURES}

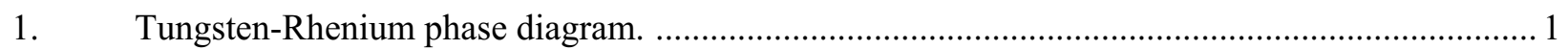

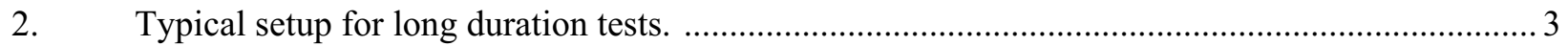

3. Measured emf of Type $\mathrm{C}$ thermocouples included in $1,500{ }^{\circ} \mathrm{C}$ test. ......................................... 4

4. Source $\mathrm{C}$ thermocouples after 2,000 hours at $1,500{ }^{\circ} \mathrm{C}$ (thermocouple rotated for insert). ........... 5

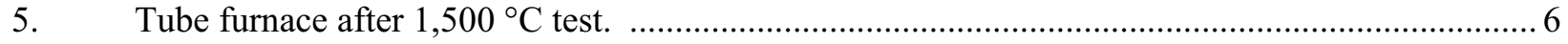

6. Source A thermocouples (A15-13 and A15-16) after 3,000 hours at 1,500 ${ }^{\circ} \mathrm{C}$. ........................ 6

7. Source $\mathrm{C}$ thermocouples (C15-18 and C15-20) after 3,000 hours at $1,500{ }^{\circ} \mathrm{C}$. ......................... 7

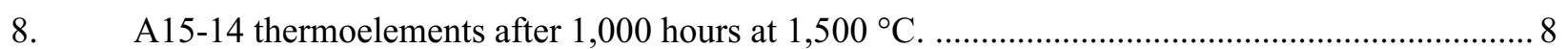

9. $\quad \mathrm{A} 15-15$ thermoelements after 2,000 hours at $1,500^{\circ} \mathrm{C}(100 \mathrm{X})$................................................. 9

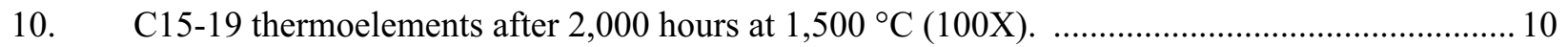

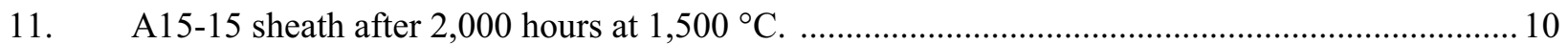

12. Outer surface of $\mathrm{A} 15-15$ and $\mathrm{C} 15-19$ sheaths after 2,000 hours at $1,500{ }^{\circ} \mathrm{C}(200 \mathrm{X})$............... 11

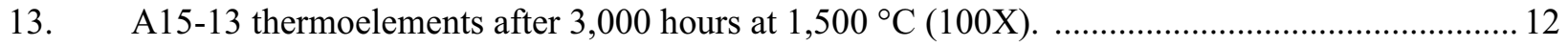

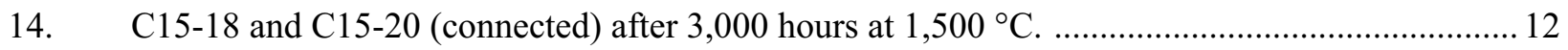

15. A15-16 thermoelements after 3,000 hours at $1,500^{\circ} \mathrm{C}(100 \mathrm{X})$. ............................................ 13

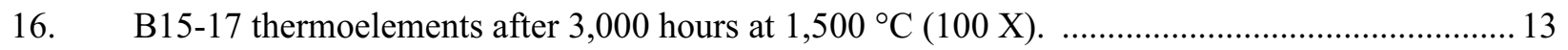

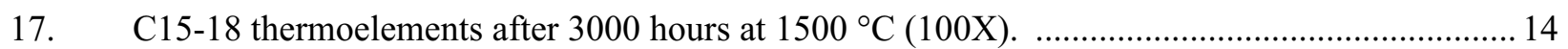

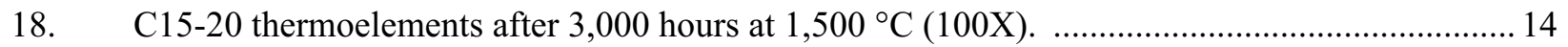

19. Representative inclusions containing higher $\mathrm{O}$ concentrations. ............................................... 15

20. Representative sheath after heating at $1,500^{\circ} \mathrm{C}$ for 3,000 hours. ......................................... 15

21. Comparisons of precipitates observed in Source A W-26\%Re thermocouple wires (magnifications varied). 16 
INL/EXT-07-13531 


\section{TABLES}

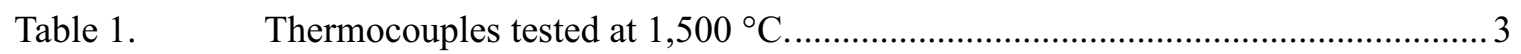

Table 2. Composition information provided by Type $\mathrm{C}$ thermocouple vendors................. 4

Table 3. Summary results for Type $\mathrm{C}$ thermocouple post test evaluations. ......................... 7

Table 4. Composition variations on A15-15 and C15-19 sheaths.................................... 11 
INL/EXT-07-13531 


\begin{abstract}
Experience with Type $\mathrm{C}$ thermocouples operating for long periods in the 1400 to $1600{ }^{\circ} \mathrm{C}$ temperature range indicate that significant decalibration occurs, often leading to expensive downtime and material waste. As part of an effort to understand the mechanisms causing drift in these thermocouples, the Idaho National Laboratory conducted a long duration test at $1500{ }^{\circ} \mathrm{C}$ containing eight Type $\mathrm{C}$ thermocouples. As report in this document, results from this long duration test were adversely affected due to oxygen ingress. Nevertheless, results provide key insights about the impact of precipitate formation on thermoelectric response. Post-test examinations indicate that thermocouple signal was not adversely impacted by the precipitates detected after 1,000 hours of heating at $1,500{ }^{\circ} \mathrm{C}$ and suggest that the signal would not have been adversely impacted by these precipitates for longer durations (if oxygen ingress had not occurred in this test).
\end{abstract}




\section{ACKNOWLEDGEMENTS}

The authors wish to acknowledge their appreciation for the Scanning Electron Microscope examinations performed by Dr. Thomas Lillo and Ms. Tammy Trowbridge. 


\section{Introduction}

Tungsten-rhenium alloy thermocouples, such as "Type C" (95 wt\%W - 5 wt\%Re versus 74 $w t \% \mathrm{~W}-26 \mathrm{wt} \% \mathrm{Re}$ ) or "Type D" (97 wt\%W - $3 \mathrm{wt} \% \mathrm{Re}$ versus $75 \mathrm{wt} \% \mathrm{~W}-25 \mathrm{wt} \% \mathrm{Re}$ ) thermocouples, may be used to measure temperatures up to $2,000^{\circ} \mathrm{C}$ and higher under protective, inert or vacuum conditions. However, chemical and physical properties of tungsten and rhenium place some limitations on their use in certain applications. For example, the high vapor pressure of rhenium places limitations on its use in vacuum applications to a maximum temperature of $1,900{ }^{\circ} \mathrm{C}$, but this selective evaporation of rhenium can be overcome if the couples are appropriately sheathed. Likewise, hydrocarbons can attack these thermocouples at temperatures above $1,000{ }^{\circ} \mathrm{C} .^{1}$

Operating experience indicates that significant drift occurs when Type $\mathrm{C}$ thermocouples are used to control processes between 1,200 and $1,500{ }^{\circ} \mathrm{C}$. As shown in Figure $1,{ }^{2}$ at temperatures below $1,500{ }^{\circ} \mathrm{C}$, the $\mathrm{W}-26 \% \mathrm{Re}$ or $\mathrm{W}-25 \% \mathrm{Re}$ alloys used for the negative legs of these thermocouples could be in a two-phase field that includes tetragonal " $\sigma$ " phase $\left(\mathrm{W}_{2} \mathrm{Re}_{3}\right)$ precipitates. If such phase separation occurs, the formation of precipitates could adversely affect the calibration of these thermocouples.

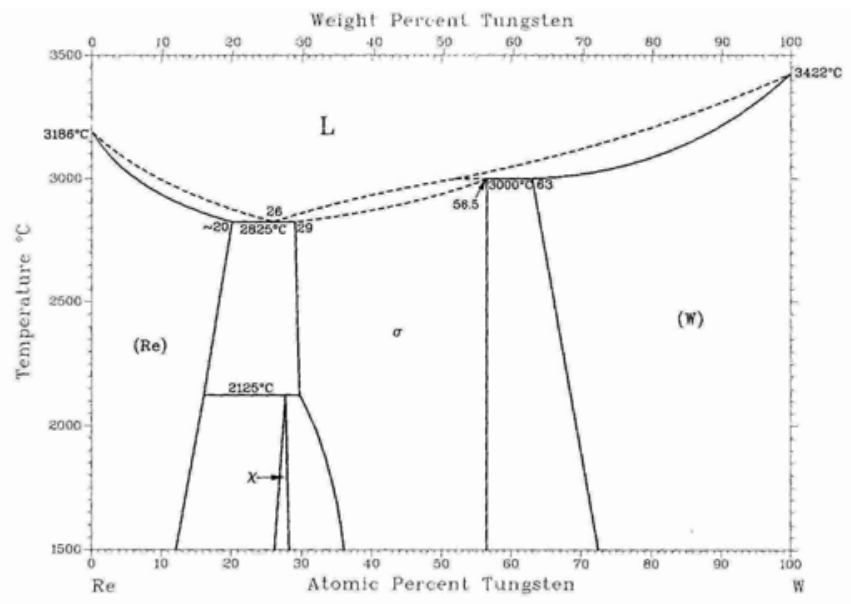

Figure 1. Tungsten-Rhenium phase diagram.

When tungsten-rhenium thermocouples are employed in a thermal neutron environment, relatively rapid decalibration has been observed. ${ }^{3}$ The thermal neutron absorption cross sections for tungsten and rhenium are relatively high, ${ }^{4}$ and thermocouple decalibration due to reduced emf has been shown to be due to transmutation associated with W/Re compositional shifts and the generation of osmium in thermal neutron environments. ${ }^{5,6}$ However, Type $\mathrm{C}$ thermocouple decalibration has also been observed to occur in fast reactor neutron spectrums, ${ }^{7}$ where the transmutation rates are much reduced. Heckelman and $\operatorname{Kozar}^{8}$ compared in-pile and out-of-pile drift of tungsten-rhenium Type D thermocouples when soaked at a nominal temperature of $1800{ }^{\circ} \mathrm{C}$ for 8000 hours. For this temperature, the in-pile thermocouples at drifted by over $300{ }^{\circ} \mathrm{C}$, whereas the out-of-pile thermocouples experienced drifts of $50{ }^{\circ} \mathrm{C}$. 
During the development of Type $\mathrm{C}$ thermocouples, it was learned that the ductility of the positive thermoelement was improved when it was doped with potassium, silicon, and aluminum compounds. Zysk and Robertson ${ }^{9}$ indicate that the negative W-26\%Re thermoelements are supplied in a stabilized (recrystallized) condition to reduce the change in emf that occurs when the Type $\mathrm{C}$ thermocouples are exposed to their operating temperature. Zysk and Robertson note that this stabilization is performed by heating thermoelements at $1,200{ }^{\circ} \mathrm{C}$, much lower than typical Type $\mathrm{C}$ thermocouple operating temperatures.

Reference 10 observed the formation of precipitates in tungsten-rhenium alloys heated up to $1,500{ }^{\circ} \mathrm{C}$ during in-pile and out-of-pile tests. Additional evidence reported in Reference 7 suggests that the occurrence of these precipitates may lead to decalibration of tungsten rhenium thermocouples when they are operated for long durations at temperatures below $1500{ }^{\circ} \mathrm{C}$. However, results from testing completed by Burns and Hurst ${ }^{11,12}$ suggest that Type D tungsten-rhenium thermocouple emf is stabilized (and precipitate formation is inhibited) if thermoelements are heated at high temperatures (at or above $2000^{\circ} \mathrm{C}$ ) prior to use (although this heating shifts the emf of the thermocouple).

To gain insights about the potential for such particulates to form and their impact on Type C thermocouple calibration, a long duration test was conducted at INL's High Temperature Test Laboratory (HTTL) in which Type C thermocouples were removed at 1,000 hour intervals, so that sectioning could be performed to assess what, if any, phase changes occurred during each heating period and correlate the appearance of such phases with any drift in the Type $\mathrm{C}$ emf. This document reports results from this test and post-test evaluations.

\section{Approach}

The long duration tests were conducted using the setup shown in Figure 2. Thermocouples were inserted into several alumina tubes $(2.5 \mathrm{~cm}$ OD) within a larger diameter alumina muffle tube $(8.9 \mathrm{~cm} \mathrm{OD})$ in a tube furnace. The tube furnace is configured to provide a continuous flow of gettered argon through each of the smaller $(2.5 \mathrm{~cm} \mathrm{OD})$ alumina tubes. Critical control of inert gas flow into each process tube is facilitated using a header fitted with adjustable needle valves. This ensures flow balance into each tube thereby protecting thermocouples from oxidation. Oxygen content within each of the smaller process tubes was periodically monitored using an oxygen monitor. Typically, oxygen concentrations of less than $0.1 \%$ were observed during testing. Enlarged photos in Figure 2 illustrate thermocouples inserted into multiple alumina process tubes within the tube furnace's larger muffle tube and the header attached to one end of each smaller alumina process tube.

The tube furnace is rated for use at temperatures up to $1800^{\circ} \mathrm{C}$. Temperature profiles indicate that there is a central region of the furnace, approximately 18 inches in length (of the total furnace length of 36 inches) that is maintained at constant temperature. Thermocouples were placed in the furnace such that their tips were at the center of the furnace, which is also in the center of this constant temperature region. Test data were automatically recorded at frequent intervals and stored on 


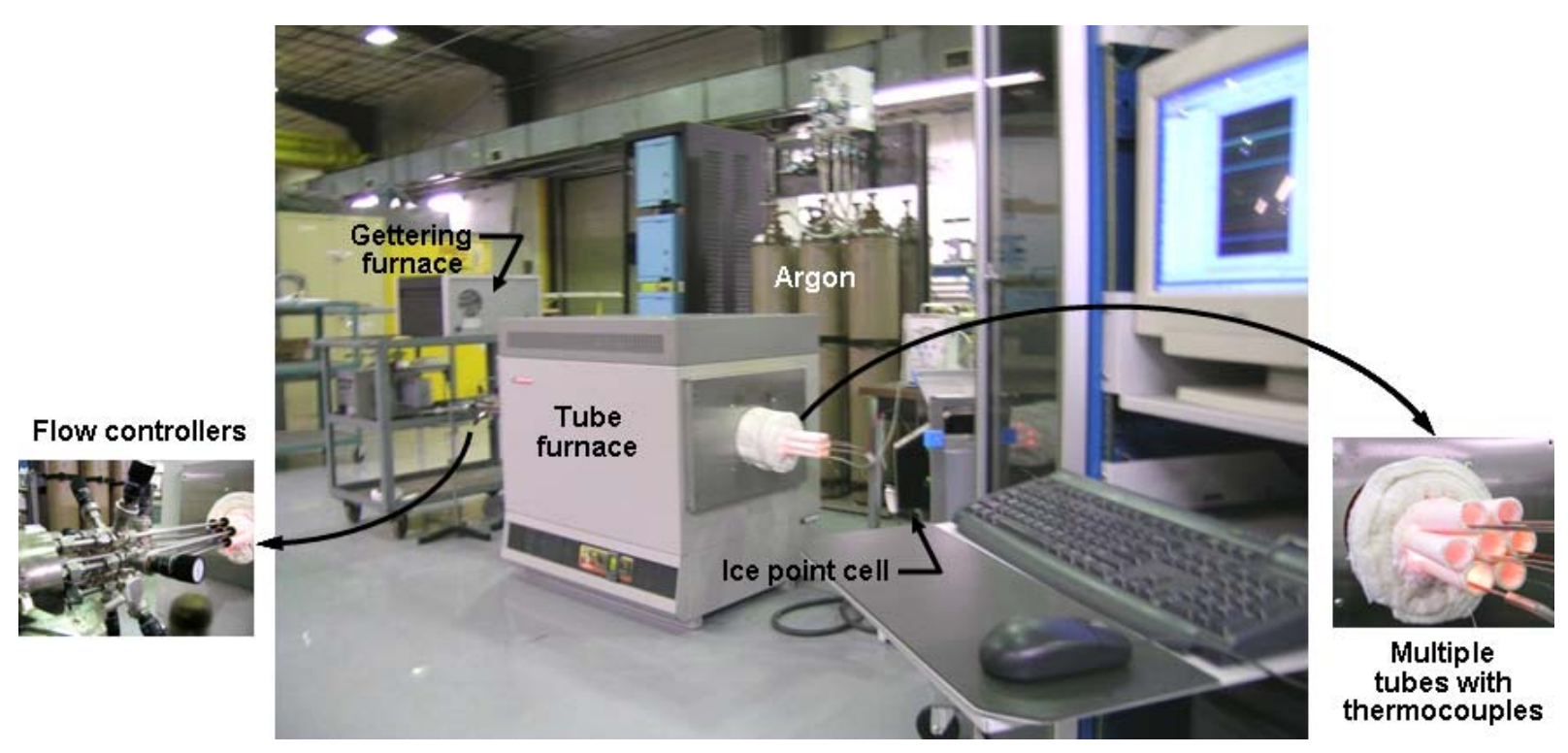

Figure 2. Typical setup for long duration tests.

a computer. As noted in Section 1, it was planned to remove thermocouples at 1,000 hour intervals. Because the furnace would be maintained at $1,500{ }^{\circ} \mathrm{C}$ throughout testing, thermocouples would slowly be withdrawn from the furnace to allow them to cool and preclude sheath oxidation.

Table 1 lists the thermocouples included in this long duration test. As indicated in this table, three sources provided Type $\mathrm{C}$ thermocouples (containing 0.020" diameter thermoelement wires, hafnia insulation and molybdenum sheaths) for this test. Source A provided four thermocouples (e.g., A15-13, A15-14, A15-15, and A15-16), Source B provided one thermocouple (B15-17), and Source C provided three thermocouples (e.g., C15-18, C15-19, and C15-20). The use of multiple smaller process tubes allowed segregation of thermocouples from different sources.

Table 1. Thermocouples tested at $1,500{ }^{\circ} \mathrm{C}$.

\begin{tabular}{|c|c|c|c|c|}
\hline \multirow[b]{2}{*}{ Designator } & \multirow[b]{2}{*}{ Description } & \multirow{2}{*}{$\begin{array}{l}\text { Room Temperature } \\
\text { Loop Resistance (ohm) }\end{array}$} & \multicolumn{2}{|c|}{$\begin{array}{c}\text { Room Temperature } \\
\text { Insulation Resistance (ohm) }\end{array}$} \\
\hline & & & "+"" wire & "_"” wire \\
\hline A15-13 & Type C - Source A & 7.50 & $>3 \mathrm{e} 11$ & $>3 \mathrm{e} 11$ \\
\hline A15-14 & Type C-Source A & 7.47 & $>1 \mathrm{e} 11$ & $>1 \mathrm{e} 11$ \\
\hline A15-15 & Type C - Source A & 7.47 & $>6 \mathrm{e} 10$ & $>6 \mathrm{e} 10$ \\
\hline A15-16 & Type C - Source A & 7.48 & $>4 \mathrm{e} 10$ & $>4 \mathrm{e} 10$ \\
\hline B15-17 & Type C - Source B & 2.75 & $>1 \mathrm{e} 12$ & $>1 \mathrm{e} 12$ \\
\hline C15-18 & Type C - Source C & 2.21 & $>1 \mathrm{e} 12$ & $>1 \mathrm{e} 12$ \\
\hline C15-19 & Type C - Source C & 2.18 & $>1 \mathrm{e} 12$ & $>1 \mathrm{e} 12$ \\
\hline $\mathrm{C} 15-20$ & Type C - Source C & 2.20 & $>1 \mathrm{e} 12$ & $>1 \mathrm{e} 12$ \\
\hline
\end{tabular}

Table 2 compares information about the materials included in the three types of Type $\mathrm{C}$ thermocouples included in this test. As shown in this table, similar materials were included in each 
thermocouple. Although thermocouple sources would not disclose vendors for thermocouple component materials to INL, sufficient information was disclosed for INL to conclude that the materials were procured from different manufacturers.

Table 2. Composition information provided by Type $\mathrm{C}$ thermocouple vendors.

\begin{tabular}{|c|c|c|c|c|}
\hline \multicolumn{2}{|c|}{ Source } & Thermoelement Wires & Insulation & Sheath \\
\hline A & Material & Tungsten- 5\% Rhenium /Tungsten - 26\% Rhenium & Hafnia & Molybdenum \\
& Comments & According to ASTM E988 & $>98 \%$ pure & $99.9 \%$ pure \\
\hline B & Material & Tungsten- 5\% Rhenium /Tungsten -26\% Rhenium & Hafnia & Molybdenum \\
& Comments & According to ASTM E988 & $>98 \%$ pure & $99.9 \%$ pure \\
\hline C & Material & Tungsten - 5\% Rhenium /Tungsten - 26\% Rhenium & Hafnia & Molybdenum \\
& Comments & According to ASTM E988 & $99.95 \%$ pure & $99.95 \%$ pure \\
\hline
\end{tabular}

\section{Test Results}

Figure 3 presents the emf data obtained from the Type $\mathrm{C}$ thermocouples during this test. As shown in this figure, all of the thermocouples experienced significant drift by the time that the test was terminated at 3,000 hours.

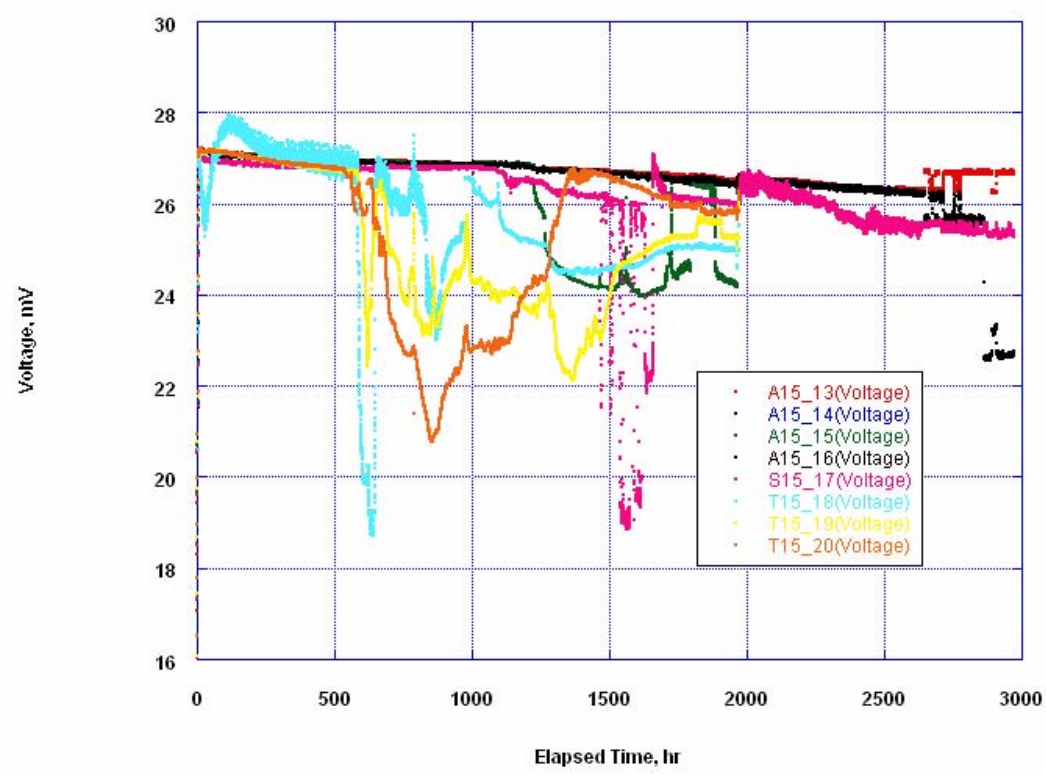

Figure 3. Measured emf of Type $\mathrm{C}$ thermocouples included in $1,500{ }^{\circ} \mathrm{C}$ test.

All thermocouples obtained from Source C experienced significant drift within the first 600 hours of the test. Thermocouple C15-18 displayed somewhat erratic behavior near the beginning 
of the test. Between 550 and 600 hours, the signals from all three Source $C$ thermocouples experienced significant degradation. The remaining Type $\mathrm{C}$ thermocouples (from Sources A and B) experienced minimal drift until after 1,000 hours. The signal from two of the Source A thermocouples, A15-13 and A13-16, didn't experience significant degradation until after 2,500 hours.

When attempting to remove the first Source $C$ thermocouple at 2,000 hours, it was discovered that all three Source $\mathrm{C}$ thermocouples had bonded together and that the outer surface of these thermocouples had significantly eroded (see Figure 4). Note that such sheath erosion was not observed on the larger diameter, thicker-walled, Source A thermocouple that was removed from the furnace at 2,000 hours, although its outer surface appeared oxidized. In addition, the oxygen monitor did not detect higher amounts of oxygen present in the smaller $(2.5 \mathrm{~cm})$ alumina tube holding the Source $\mathrm{C}$ thermocouples.

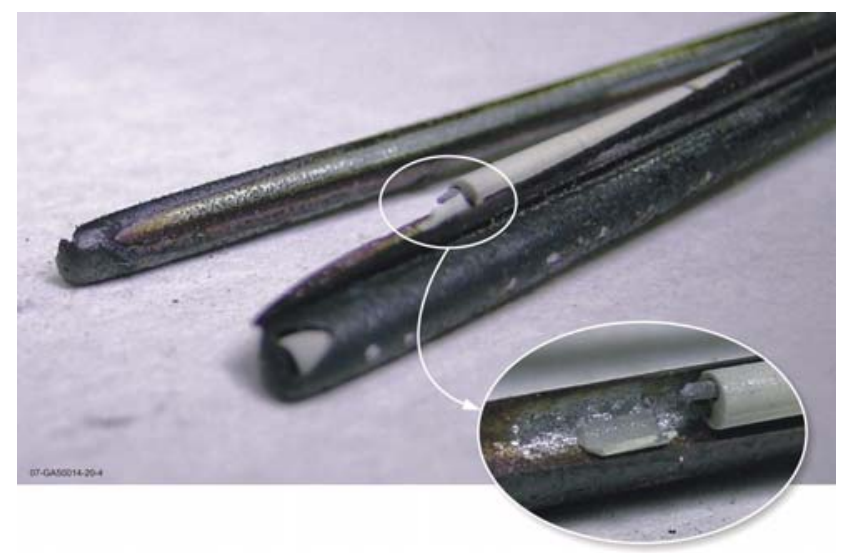

Figure 4. Source $\mathrm{C}$ thermocouples after 2,000 hours at $1,500{ }^{\circ} \mathrm{C}$ (thermocouple rotated for insert).

By 3,000 hours, the signal from all Type $\mathrm{C}$ thermocouples had experienced more degradation than anticipated. Hence, it was decided to terminate the test at this time. During removal of the Type $\mathrm{C}$ thermocouples, it was observed that all Type $\mathrm{C}$ thermocouples had bonded together and experienced significant oxidation and erosion.

\section{Post-test Visual Examinations}

During disassembly of the test, significant deposits of oxidized material were observed on the flow tubes containing the thermocouples (see Figure 5). After removal from the tube furnace, it was found that these tubes were "bowed" and fractured at certain locations. Such fractures could have allowed air to come into contact with the thermocouples during testing, although the time when air ingress occurred was unknown. As shown in Figures 6 and 7, all Type $C$ thermocouples had experienced significant oxidation by the time that the test was terminated. 


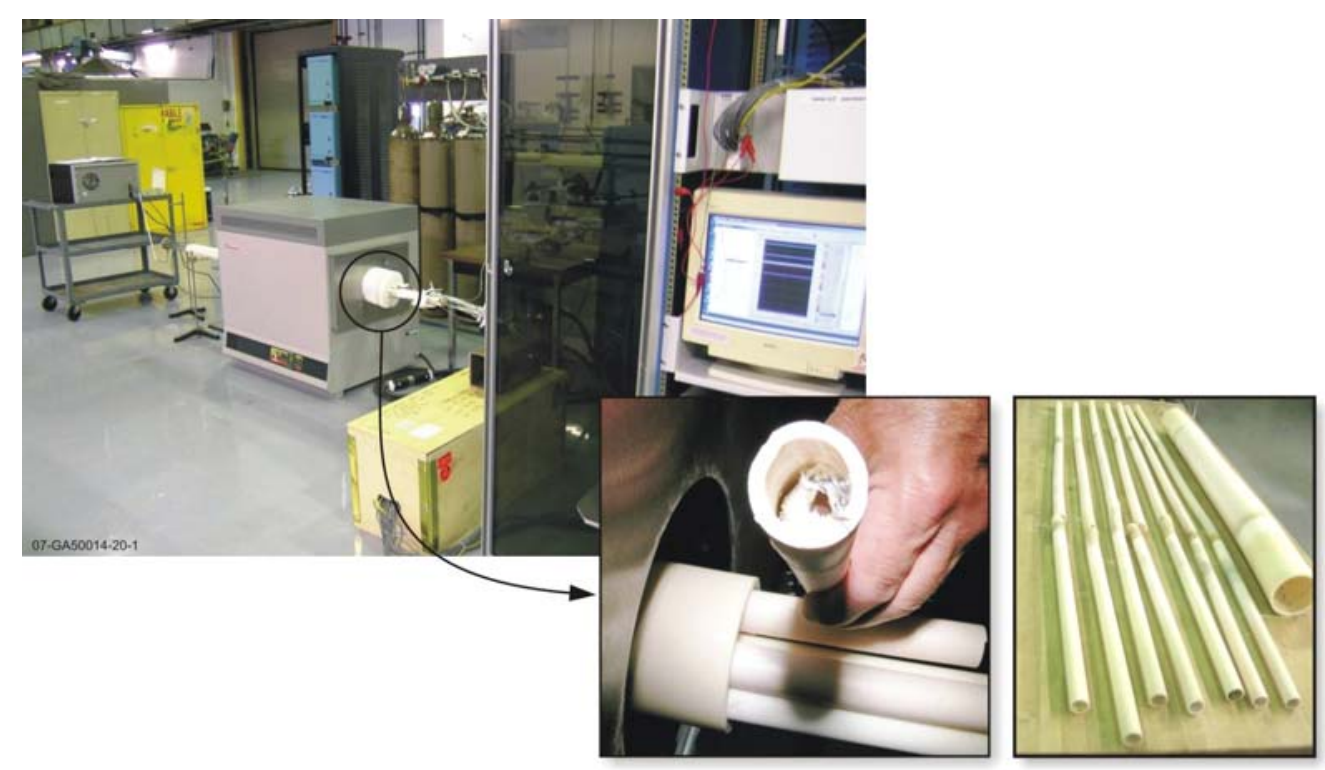

Figure 5. Tube furnace after $1,500{ }^{\circ} \mathrm{C}$ test.

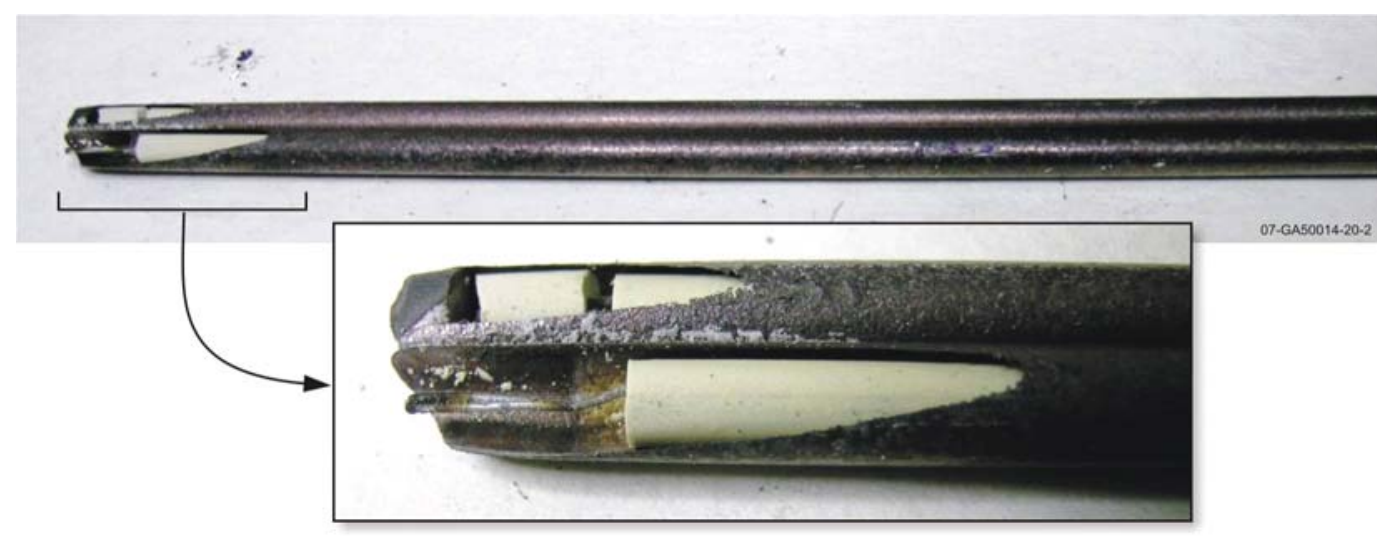

Figure 6. Source A thermocouples (A15-13 and A15-16) after 3,000 hours at 1,500 ${ }^{\circ} \mathrm{C}$.

\section{Post-test Examinations}

Post-test examinations of the Type $\mathrm{C}$ thermocouples included macro photographs and Scanning Electron Microscopy (SEM) evaluations to determine oxygen content and compositions. In particular, SEM evaluations focused on the composition of tungsten, rhenium, molybdenum, hafnium, and oxygen in each wire and the sheath. In some thermoelement wires, a core region was surrounded by a more porous outer region. In other wires, precipitates had formed. In such cases, compositional analyses were conducted on each region and the precipitates.

Table 3 summarizes SEM evaluations for the compositions of wires and precipitates observed in the Type $\mathrm{C}$ thermocouples during this test. Note that the wires of thermocouples were arbi- 


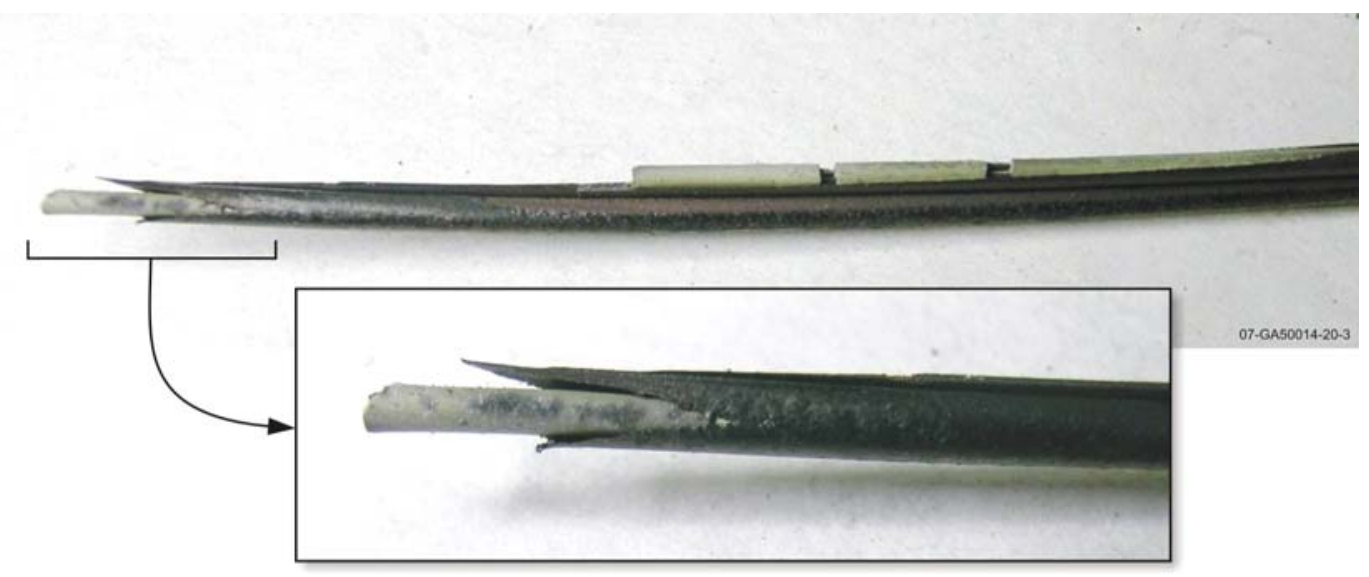

Figure 7. Source $\mathrm{C}$ thermocouples (C15-18 and $\mathrm{C} 15-20)$ after 3,000 hours at $1,500{ }^{\circ} \mathrm{C}$.

trarily labeled "A" and "B" during sectioning, and SEM evaluations verified which wire was W$26 \%$ Re and which was $\mathrm{W}-5 \% \mathrm{Re}$. Visually, the $\mathrm{W}-5 \% \mathrm{Re}$ wire could usually be identified by the deep crack that occurs during the manufacturing process.

Table 3. Summary results for Type $\mathrm{C}$ thermocouple post test evaluations.

\begin{tabular}{|c|c|c|c|c|c|c|c|c|c|c|c|c|c|c|}
\hline \multirow[b]{2}{*}{ ID } & \multirow{2}{*}{$\begin{array}{c}\text { Exposure } \\
\text { Duration, } \\
\text { hrs }\end{array}$} & \multicolumn{5}{|c|}{ W-5\%Re } & \multicolumn{8}{|c|}{ W-26\% Re } \\
\hline & & ID & Porous? & Cracked? & $w t \% w$ & $>1 \%$ & ID & Porous? & Cracked? & wt $\%$ W & $>1 \%$ & Precipitate ${ }^{\mathrm{a}}$ & wt \% W & $w t \% R e$ \\
\hline A15-13 & 3,000 & $\mathbf{A}$ & Throughout & Yes & $64.5-91.96$ & $\begin{array}{l}\mathrm{O}, \mathrm{Mo}, \\
\mathrm{Re}, \mathrm{Mg}, \\
\mathrm{Al}, \mathrm{Hf}^{b}\end{array}$ & B & Near edge & Yes & 73.7 & $\mathrm{O}$ & Yes & 51.1 & 46.4 \\
\hline A15-14 & 1,000 & B & $\begin{array}{l}\text { Near Edge } \\
\text { and Crack }\end{array}$ & Yes & $90.11-92.36$ & $\mathrm{O}, \mathrm{Al}, \mathrm{Hf}$ & $\mathbf{A}$ & Near edge & Near Edge & $74.0-74.2$ & $\mathrm{O}, \mathrm{H}^{\mathrm{c}}$ & Yes & $50.2-52.4$ & $43.0-47.2$ \\
\hline A15-15 & 2,000 & $\mathbf{A}$ & Throughout & Yes & $47.2-77.8$ & $\begin{array}{l}\text { O, Mo, } \\
\text { Hf, Al, }\end{array}$ & B & $\begin{array}{l}\text { Limited } \\
\text { region and } \\
\text { near edge }\end{array}$ & No & 74.0 & $\mathrm{O}, \mathrm{Mo}^{\mathrm{d}}$ & Yes & 49.8 & 45.8 \\
\hline A15-16 & 3,000 & B & Throughout & Yes & $68.9-82.6$ & $\mathrm{O}, \mathrm{Mo}^{\mathrm{e}}$ & $\mathbf{A}$ & $\begin{array}{l}\text { Outer } \\
\text { regions }\end{array}$ & Yes & $73.1^{\mathrm{f}}$ & $\mathrm{O}$ & Yes & 49.8 & 47.8 \\
\hline B15-17 & 3,000 & $\mathbf{A}$ & Throughout & Yes & $61.0-91.5$ & $\begin{array}{l}\mathrm{O}, \mathrm{Mo}, \mathrm{Fe}, \\
\mathrm{Hf}, \mathrm{Mg}^{\mathrm{e}}\end{array}$ & B & $\begin{array}{c}\text { Most outer } \\
\text { regions }\end{array}$ & No & $73.1-76.2^{\mathrm{g}}$ & $\mathrm{O}$ & Yes & $\mathrm{NA}^{\mathrm{h}}$ & $\mathrm{NA}^{\mathrm{h}}$ \\
\hline C15-18 ${ }^{i}$ & 3,000 & $\mathbf{A}$ & Throughout & Yes & $38.3-93.2$ & $\mathrm{O}, \mathrm{Mo}$ & B & $\begin{array}{l}\text { Outer } \\
\text { region }\end{array}$ & No & 71.7 & $\mathrm{O}, \mathrm{Mo}$ & Yes & 52.7 & 43.1 \\
\hline C15-19 & 2,000 & $\mathbf{A}$ & Throughout & No & $48.1-86.8$ & O, Mo & B & Near edge & No & 72.2 & $\mathrm{O}$ & Yes & 51.8 & 45.7 \\
\hline C15-20 ${ }^{i}$ & 3,000 & $\mathbf{A}$ & Throughout & Yes & $60.7-81.7$ & $\mathrm{O}, \mathrm{Mo}$ & B & $\begin{array}{l}\text { Outer } \\
\text { regions }\end{array}$ & No & 75.2 & $\mathrm{O}$ & Yes & 51.7 & 44.8 \\
\hline
\end{tabular}

a. Precipitates in central region of wire found to primarily contain $\mathrm{W}$ and Re with less than $2 \mathrm{wt} \% \mathrm{O}$.

b. $\mathrm{Mg}, \mathrm{Al}$, and $\mathrm{Hf}$ only near outer edge or pores of wire

c. $\mathrm{Hf}$ and lower concentrations of $\mathrm{W}$ (down to $48.5 \mathrm{wt} \%$ )found in deposit on edge of this wire.

d. Mo concentrations up to $27.2 \mathrm{wt} \%$ found on outer edge of wire (reducing W concentration to $50.2 \mathrm{wt} \%$ ).

e. $\mathrm{Hf}$ and $\mathrm{Mg}$ detected in pore.

f. Outer porous ring composition contained W (34.3-52.9\%), Re (30.8-54.6\%), and O (1.4.-4.2\%)

g. Outer porous ring contained $67.1 \% \mathrm{~W}, 7.5 \% \mathrm{Re}, 11.6 \% \mathrm{O}, 7.4 \% \mathrm{Hf}, 2.3 \% \mathrm{Mg}$, and $1.4 \% \mathrm{Mg}$

h. Values for precipitates observed in this thermoelement aren't available.

i. C15-18 and C15-20 bonded together. 


\subsection{Endstate after 1,000 Hours of Heating}

Only one Type $\mathrm{C}$ thermocouple, A15-14, was removed after 1,000 hours of heating. As noted above, it was originally planned to conduct the test for 4,000 hours and remove a thermocouple from each source at 1,000 hour increments. Hence, removal after 1,000 hours was limited to a thermocouple fabricated by Source A, which was the only source that supplied the requested four thermocouples. As shown in Figure 3, the signal from all four Source A thermocouples was stable after 1,000 hours at $1,500^{\circ} \mathrm{C}$. Hence, the removed thermocouple, A15-14, was randomly selected.

As shown in Figure 8, grain structure formation and some outer surface degradation could be seen in both thermoelement wires of the A15-14 thermocouple after heating. It should be noted that it isn't known how much of the grain growth occurred during heating and how much occurred during the "stabilization" process for the Type C thermocouple wires prior to manufacturer calibration. SEM evaluations did not detect significant amounts of molybdenum in either wire. Precipitates were observed in the W-26\%Re wire. These precipitates were composed of between 50$52 \mathrm{wt} \% \mathrm{~W}$ and $43-47 \mathrm{wt} \% \mathrm{Re}$ (consistent with the phase separation suggested by Figure 1 ). The W$5 \%$ Re wire showed the expected deep crack. SEM evaluations did not detect any significantly different compositions in material in the crack (although a "shiny" precipitate could be observed on the inner surface of the crack at larger magnifications). Oxygen concentrations in both wires typically varied from 1 to $2 \mathrm{wt} \%$. Wire exterior surfaces appeared to have experienced minimal attack. However, a precipitate found on the outer region of the W-26\%Re wire contained higher concentrations of W (up to 46\%) and slightly higher concentrations of O. Minimal change was observed in the sheath.

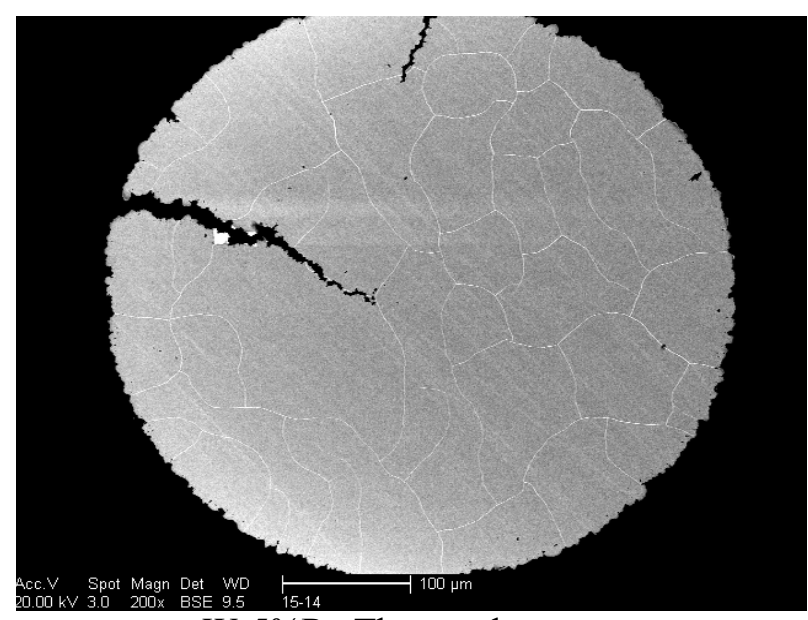

W-5\%Re Thermoelement

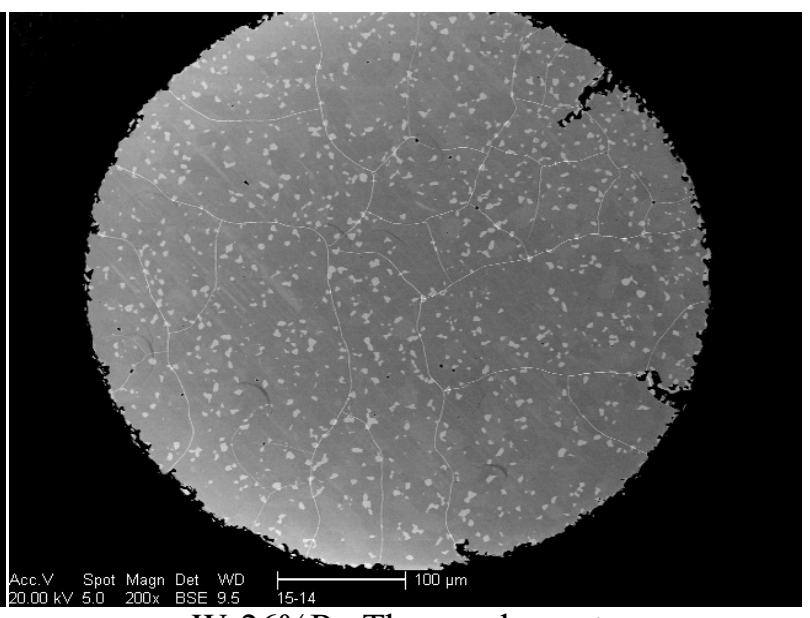

W-26\%Re Thermoelement

Figure 8. A15-14 thermoelements after 1,000 hours at $1,500{ }^{\circ} \mathrm{C}$. 


\subsection{Endstate after 2,000 Hours of Heating}

After 2000 hours of heating, thermocouples A15-15 and C15-19 were removed. As shown in Figure 3, the signal from all three Source $C$ thermocouples degraded within the first 650 hours of testing, but the A15-15 was the only Source A thermocouple with a degraded signal. Hence, the Source C thermocouple removed, C15-19, was randomly chosen; but the selected Source A thermocouple, A15-15, was chosen because its signal had degraded more than the remaining Source A thermocouples.

Figures 9 and 10 show thermoelement wires and sheaths of these thermocouples after 2,000 hours of heating. It is interesting to observe that the W-5\%Re wires in both of these thermocouples experienced similar degradation. Wire compositions in non-porous locations of the W-5\%Re wires varied significantly, containing tungsten (39-87 wt $\%$ ), rhenium (2-21 wt $\%)$, and molybdenum (13-43 wt \%). Voids within the pores were found to contain inclusions composed of hafnia (up to $24 \mathrm{wt} \%$ ). Oxygen content in both wires remained between 1 and $2 \mathrm{wt} \%$ at most locations, although up to $25 \mathrm{wt} \%$ oxygen was detected in porous region of the W-5\%Re wire. Precipitates found within the $\mathrm{W}-26 \% \mathrm{Re}$ wires contained between $50-52 \% \mathrm{~W}$ and approximately $46 \% \operatorname{Re}$ (consistent with the phase separation suggested by Figure 1). Molybdenum was not detected in the W$26 \%$ Re wire except where pores were observed (near a limited region at the center of thermocouple 15-15 and on the exterior surfaces of 15-15 and 15-19). The pores extending into the center of the $\mathrm{W}-26 \%$ Re wire in $15-15$ contained Mo (1-4 wt \%), W(50-74 wt \%), Re(14-45 wt\%), and $\mathrm{Hf}(1-$ $4 \mathrm{wt} \%)$. Similar compositions were measured on the exterior surfaces of both wires: W(39-80 $\mathrm{wt} \%), \operatorname{Re}(5-21 \mathrm{wt} \%), \operatorname{Mo}(14-31 \mathrm{wt} \%), \operatorname{Hf}(0-1 \mathrm{wt} \%)$, and O (2-7 wt $\%)$.

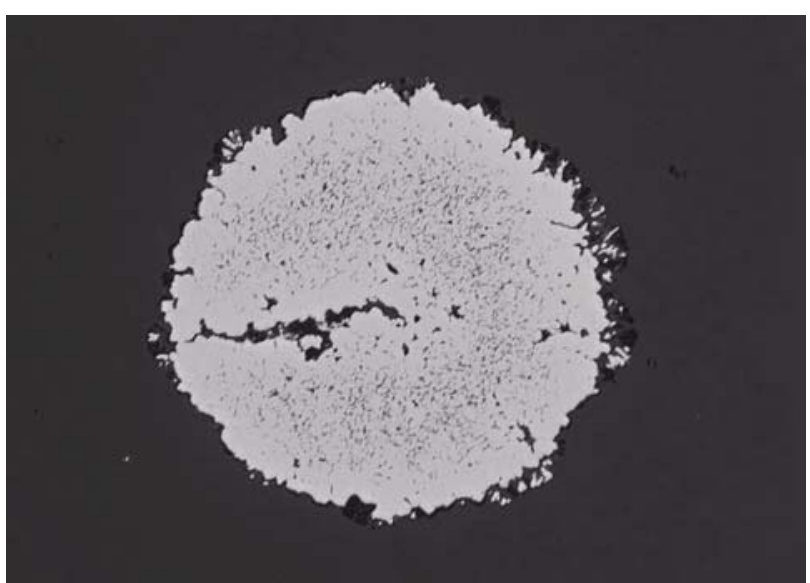

W-5\%Re Thermoelement

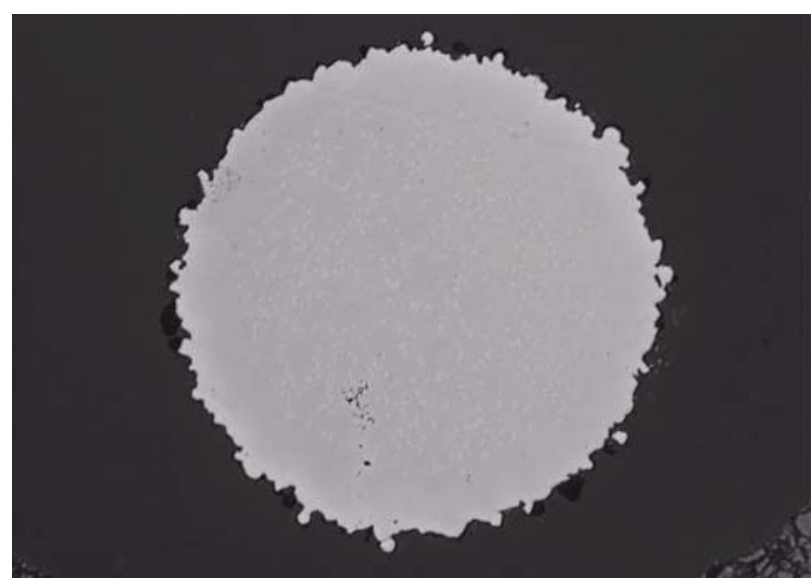

W-26\%Re Thermoelement

Figure 9. A15-15 thermoelements after 2,000 hours at $1,500{ }^{\circ} \mathrm{C}(100 \mathrm{X})$.

Figure 11 shows representative sections of the inner surface of the molybdenum sheath from the A15-15 thermocouple. As shown in this figure, the interior of the sheath near each wire of this thermocouple differed in appearance, with more degradation occurring near the $\mathrm{W}-5 \% \mathrm{Re}$ wire. Figure 12 shows representative sections from the outer surface of the thermocouples, A15-15 and C15-19. 


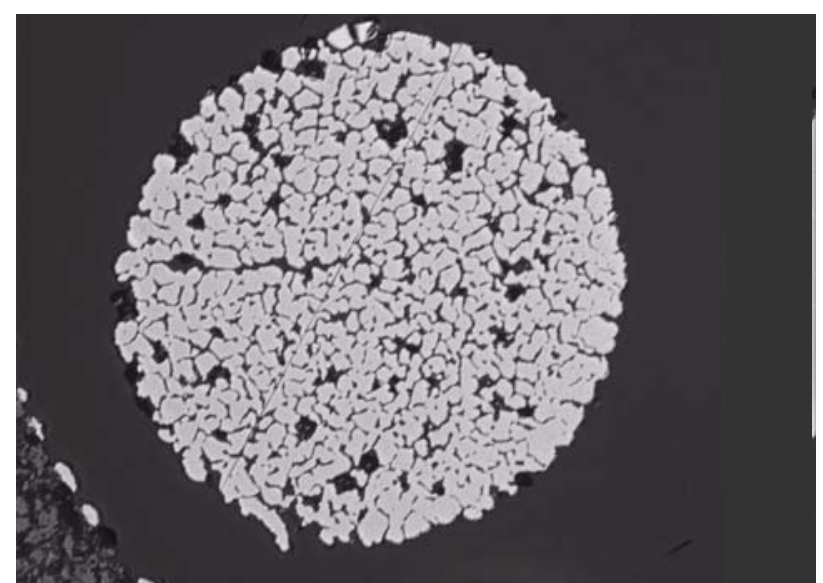

W-5\%Re Thermoelement

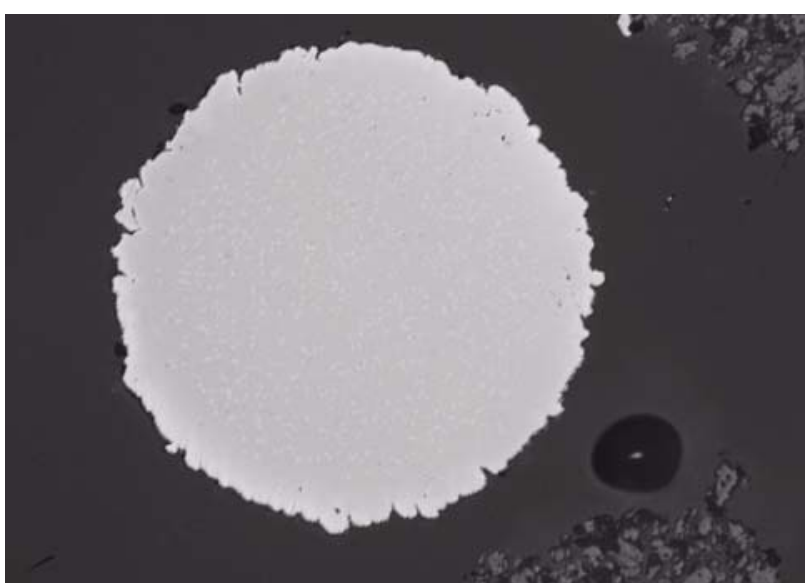

W-26\%Re Thermoelement

Figure 10. C15-19 thermoelements after 2,000 hours at $1,500{ }^{\circ} \mathrm{C}(100 \mathrm{X})$.

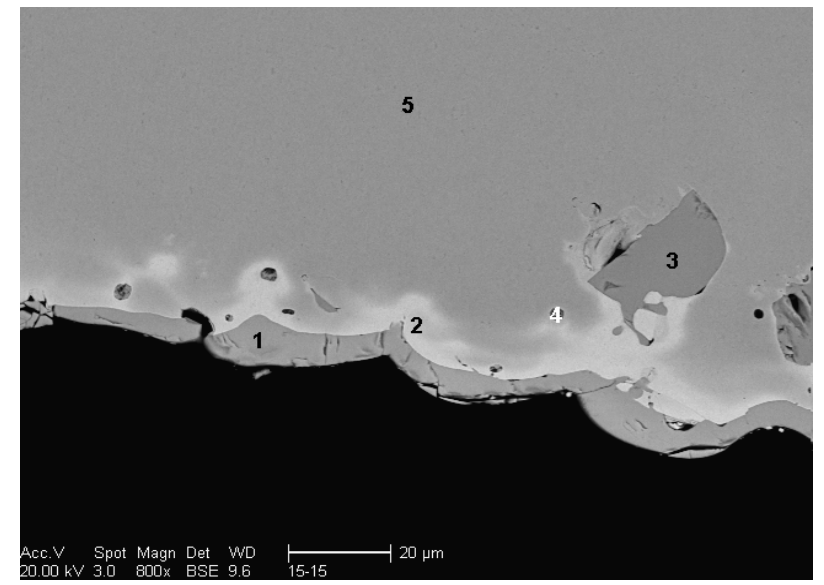

Near Thermoelement W-5\%Re

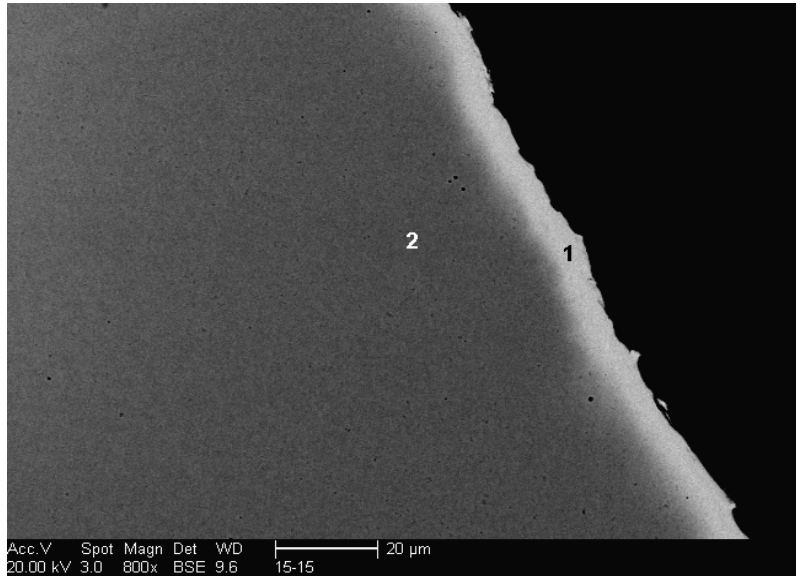

Near Thermoelement W-26\%Re

Figure 11. A15-15 sheath after 2,000 hours at $1,500{ }^{\circ} \mathrm{C}$.

As indicated in Table 4, higher concentrations of tungsten were detected on the inner surface of the A15-15 molybdenum sheath. SEM evaluations indicate that the inner surface of the A15-15 and $\mathrm{C} 15-19$ sheaths contained higher concentrations of tungsten (up to $70 \mathrm{wt} \%$ on the inner surface of the C15-19 thermocouple). 


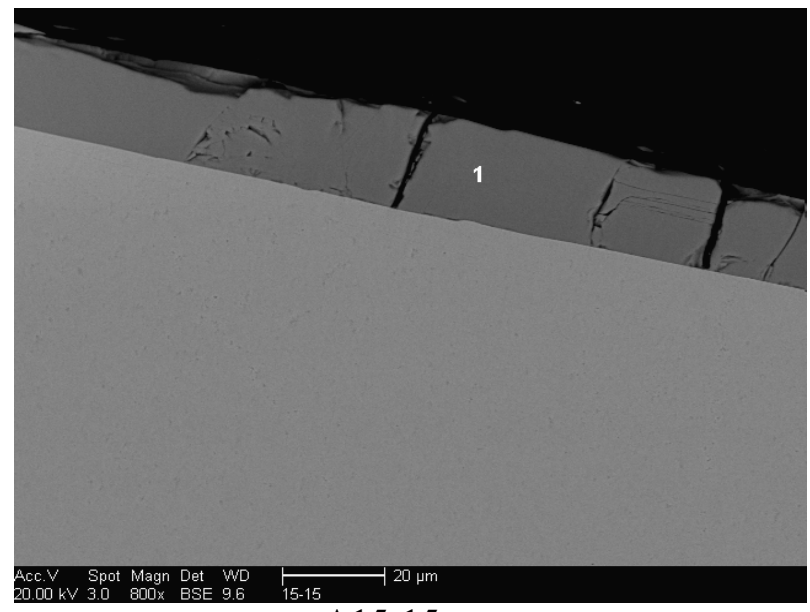

A15-15

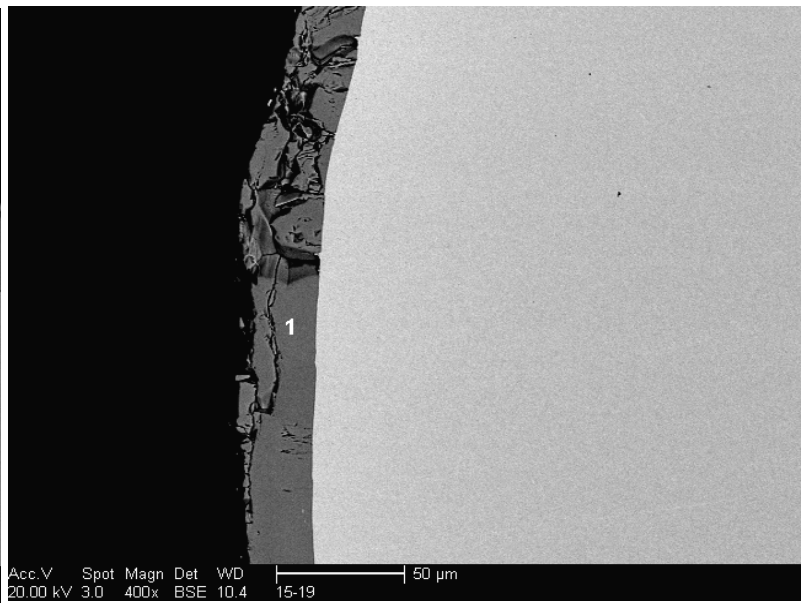

C15-19

Figure 12. Outer surface of A15-15 and C15-19 sheaths after 2,000 hours at $1,500{ }^{\circ} \mathrm{C}(200 \mathrm{X})$.

Table 4. Composition variations on A15-15 and C15-19 sheaths.

\begin{tabular}{|c|c|c|c|c|c|c|}
\hline \multirow{2}{*}{\multicolumn{2}{|c|}{ Sheath Location }} & \multicolumn{5}{|c|}{ Weight Percent } \\
\hline & & $\mathbf{W}$ & $\mathbf{R e}$ & Мo & Hf & $\mathbf{O}$ \\
\hline \multirow{5}{*}{$\begin{array}{l}\text { Inner surface of A15-15 near A wire } \\
\text { (see Figure 11a) }\end{array}$} & $\mathbf{1}$ & 50 & 2 & 36 & 2 & 9 \\
\hline & 2 & 53 & 1 & 44 & 0 & 2 \\
\hline & 3 & 33 & 0 & 51 & 2 & 14 \\
\hline & 4 & 23 & 1 & 57 & 3 & 13 \\
\hline & 5 & 2 & 1 & 91 & 1 & 5 \\
\hline \multirow{2}{*}{$\begin{array}{l}\text { Inner surface of A15-15 near B wire } \\
\text { (see Figure 11b) }\end{array}$} & 1 & 54 & 2 & 37 & 1 & 5 \\
\hline & 2 & 3 & 1 & 89 & 1 & 4 \\
\hline Outer surface of A15-15 (see Figure 12) & 1 & 2 & 2 & 78 & 1 & 17 \\
\hline Outer surface of C15-19 (see Figure 12) & $\mathbf{1}$ & 3 & 2 & 75 & 2 & 17 \\
\hline
\end{tabular}

\subsection{Endstate after 3,000 Hours of Heating}

As discussed in Section 3, the signal from all of the Type $\mathrm{C}$ thermocouples had significantly degraded after 3,000 hours. Post-test examination showed that the sheaths had experienced significant oxidation and erosion. Many, such as the C15-18 and C15-20 thermocouples shown in Figure 13, had "bonded" together. SEM analysis of the bonded region detected Mo (68-88 wt\%, with lower concentrations at points 1 and 7), Re (1-23 wt \% with higher concentrations at points 1 and 5), W (2-10 wt \%, with higher concentrations at points 7 and 9), and $\mathrm{O}$ (3-23 wt $\%$, with higher concentrations at points 4 and 10).

Figures 14 through 18 show thermoelement wires and sheaths of the thermocouples that were heated for 3000 hours. It is interesting to observe that both wires in each of these thermocouples experienced similar degradation (Table 3 summarizes measured wire compositions). Furthermore, 


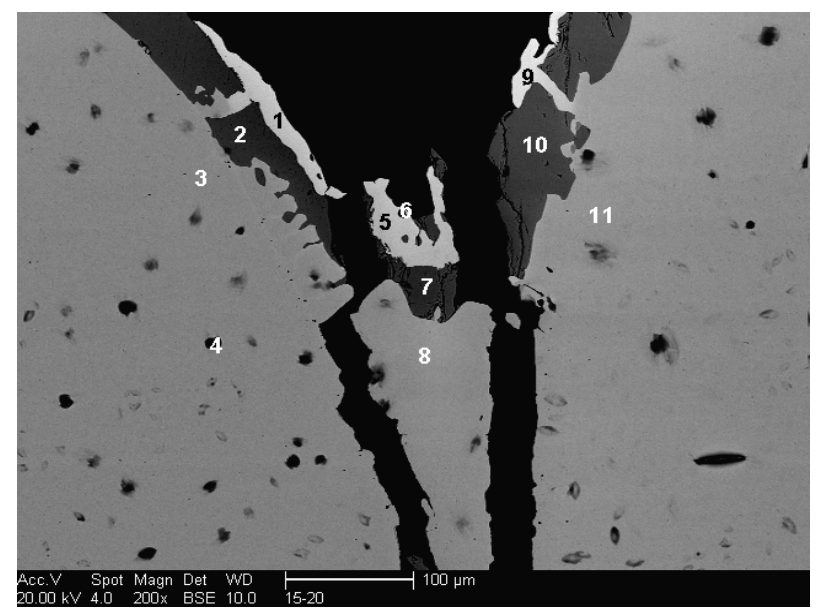

Figure 13. $\mathrm{C} 15-18$ and $\mathrm{C} 15-20$ (connected) after 3,000 hours at $1,500{ }^{\circ} \mathrm{C}$.

the observed degradation in both wires was more severe than observed in the thermocouples that had been heated for 2,000 hours. In the case of the $\mathrm{W}-26 \% \mathrm{Re}$ wires, the outer half of the wire is porous. Oxygen concentrations within all of the wires was between 2-3 wt $\%(20-23$ at $\%)$, although SEM evaluations indicated oxygen concentrations of up to $14 \mathrm{wt} \%$ (52-59 at $\%)$ in inclusions of porous regions (see examples in Figure 19). Molybdenum concentrations varied from 0 to $28 \mathrm{wt} \%$. Precipitates in the $\mathrm{W}-26 \%$ Re wire ranged between 50 and $56 \mathrm{wt} \% \mathrm{~W}$ and 43 and $46 \mathrm{wt} \%$ Re (consistent with the phase separation suggested by Figure 1).

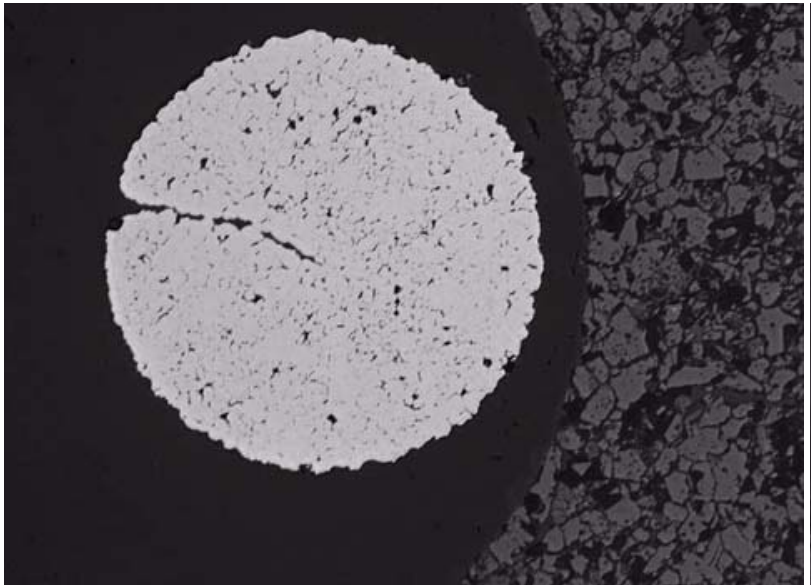

W-5\%Re Thermoelement

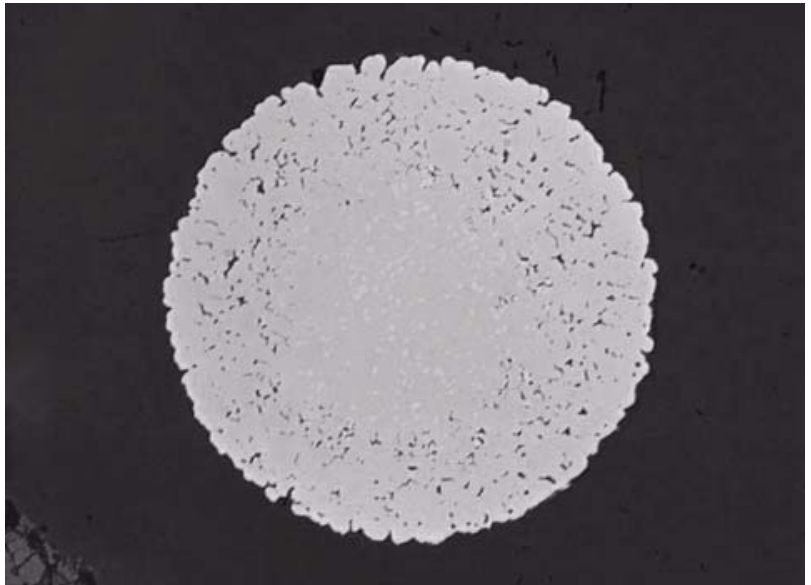

W-26\%Re Thermoelement

Figure 14. A15-13 thermoelements after 3,000 hours at $1,500{ }^{\circ} \mathrm{C}(100 \mathrm{X})$.

The three regions shown in Figure 20 for 15-13 are representative of thermocouple sheaths heated for 3,000 hours. Higher oxygen concentrations were detected on the inner surface (16 wt\% $\mathrm{O}$ at location 3$)$ and outer surface (16 wt\% $\mathrm{O}$ at location 1) with lower concentrations 


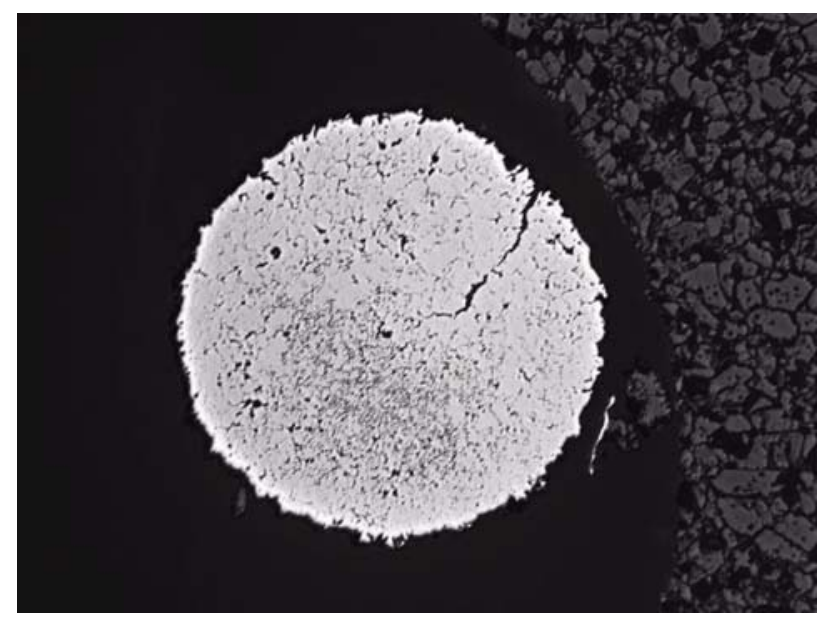

W-5\%Re Thermoelement

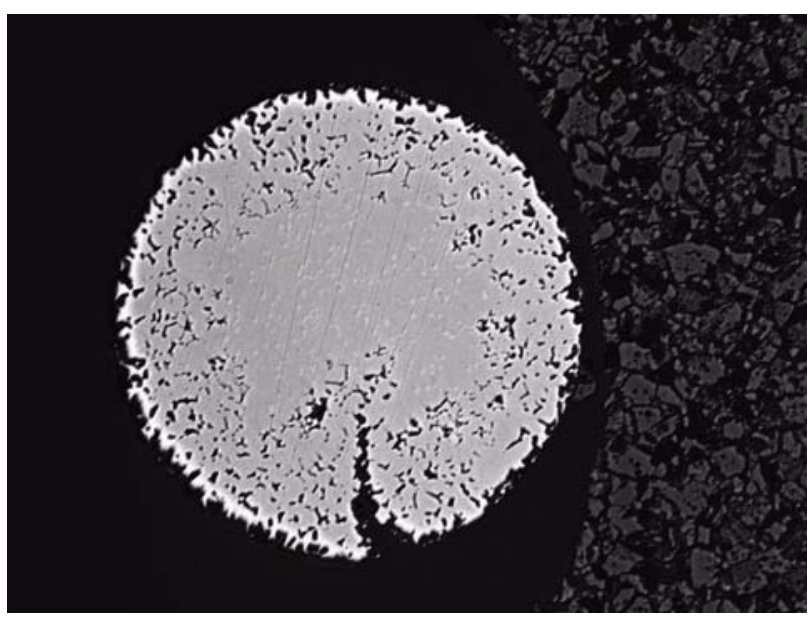

W-26\%Re Thermoelement

Figure 15. A15-16 thermoelements after 3,000 hours at $1,500{ }^{\circ} \mathrm{C}(100 \mathrm{X})$.

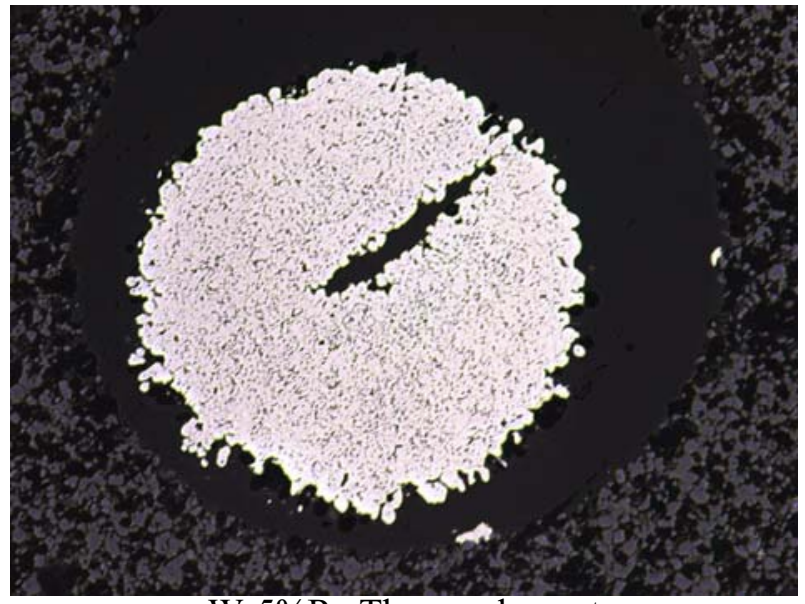

W-5\%Re Thermoelement

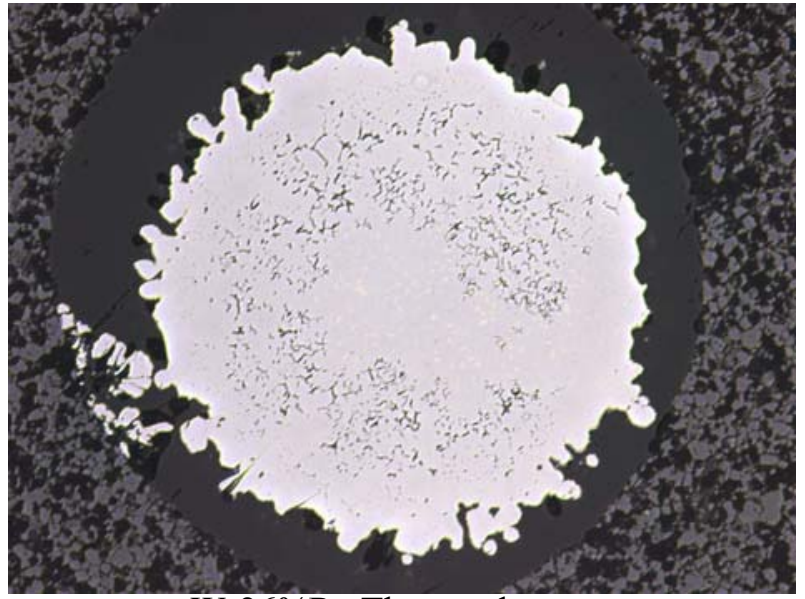

W-26\%Re Thermoelement

Figure 16. B15-17 thermoelements after 3,000 hours at $1,500{ }^{\circ} \mathrm{C}(100 \mathrm{X})$.

( $5 \mathrm{wt} \% \mathrm{O}$ at location 2$)$ in the central region. Significant amounts of tungsten $(42 \mathrm{wt} \%)$ were detected on the inner sheath surface (location 3); whereas, less than $2 \mathrm{wt} \%$ tungsten was detected at other locations (less than $1 \mathrm{wt} \%$ at location 2 and less than $2 \mathrm{wt} \%$ at location 3 . The balance at all three locations was primarily molybdenum ( $79 \mathrm{wt} \%$ at location 1, $91 \mathrm{wt} \%$ at location 2, and 39 $\mathrm{wt} \%$ at location 3 ).

\section{Material Property Considerations}

SEM evaluations suggest that molybdenum, rhenium, and tungsten in these thermocouples oxidized. In addition, the porous degradation of thermoelement wires appears to always occur 


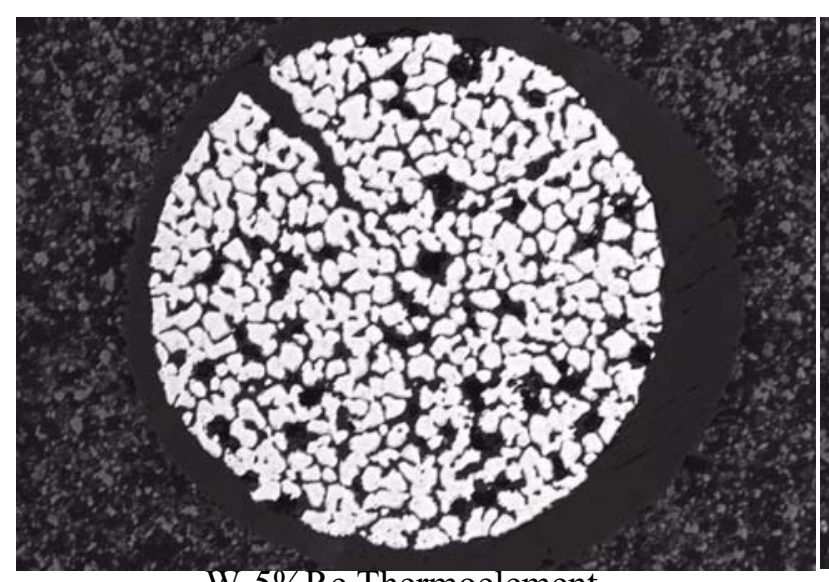

W-5\%Re Thermoelement

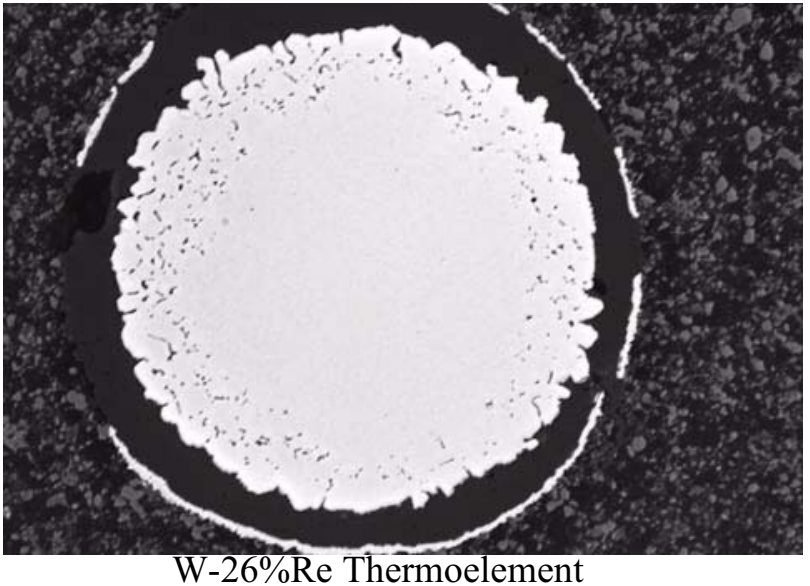

$\mathrm{W}-26 \%$ Re Thermoelement

Figure 17. $\mathrm{C} 15-18$ thermoelements after 3000 hours at $1500{ }^{\circ} \mathrm{C}(100 \mathrm{X})$.

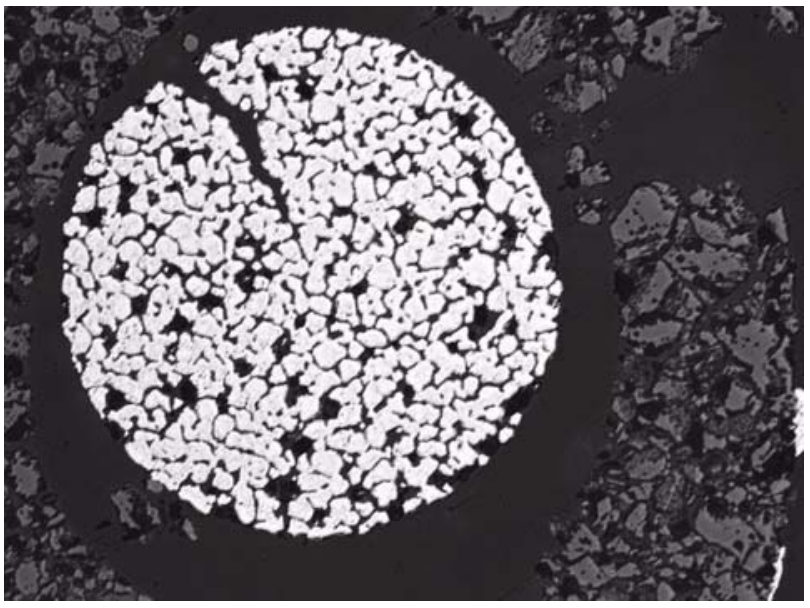

W-5\%Re Thermoelement

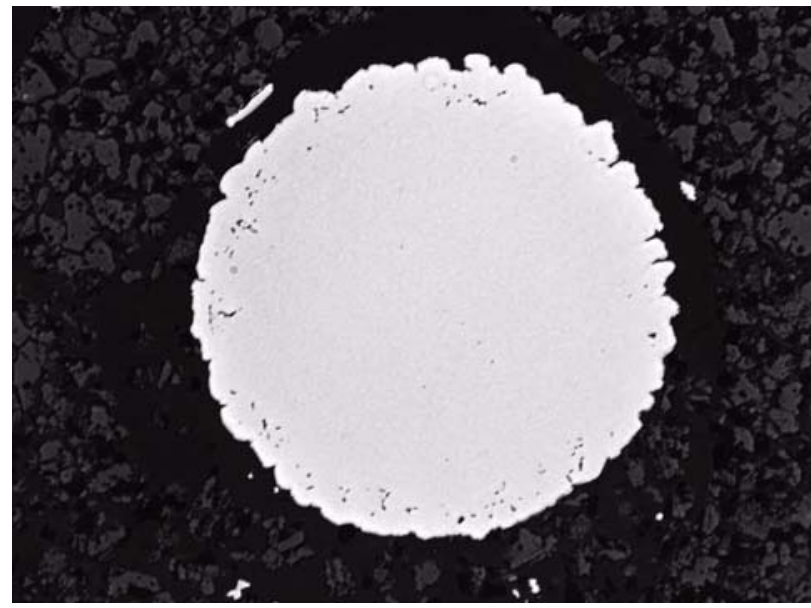

W-26\%Re Thermoelement

Figure 18. $\mathrm{C} 15-20$ thermoelements after 3,000 hours at $1,500{ }^{\circ} \mathrm{C}(100 \mathrm{X})$.

when molybdenum was detected. Evaluations suggest that tungsten was more easily transported from the matrix in a vapor state (since the $\mathrm{W}-5 \% \mathrm{Re}$ wire suffered more degradation) and that the molybdenum partially replaced vaporized tungsten.

Material property information ${ }^{13,14}$ indicates that certain oxides of these elements experience boiling at temperatures lower than $1,500^{\circ} \mathrm{C}$ (e.g., $\mathrm{MoO}_{3}$ vaporizes at $1,155^{\circ} \mathrm{C}, \mathrm{WO}_{2}$ vaporizes at $1,470{ }^{\circ} \mathrm{C}$, and $\mathrm{Re}_{2} \mathrm{O}_{7}$ vaporizes at $360{ }^{\circ} \mathrm{C}$ ). Negative formation energies are estimated for these oxides at $1,500{ }^{\circ} \mathrm{C}$. Hence, material property information suggests that all of these oxides could easily be vaporized at $1,500{ }^{\circ} \mathrm{C}$. However, results show that tungsten oxide was more readily transported.

Evaluations also indicate that precipitate composition and appearance remained similar, irrespective of heating duration. Detected compositions ranged from 50-53wt $\% \mathrm{~W}$ and $43-46 \mathrm{wt} \% \mathrm{Re}$, irrespective of thermocouple source or heating time. Note that this composition is consistent with 


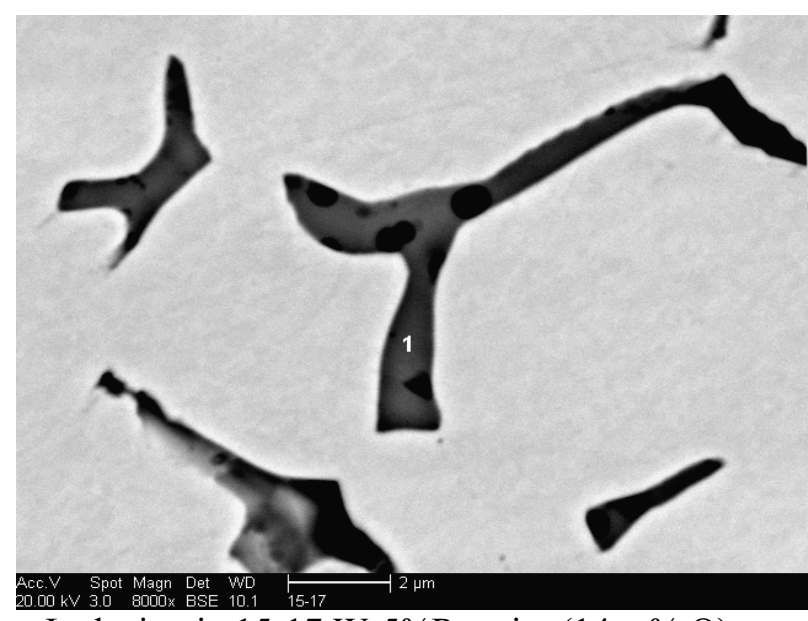

Inclusion in $15-17 \mathrm{~W}-5 \% \operatorname{Re}$ wire $(14 \mathrm{wt} \% \mathrm{O})$

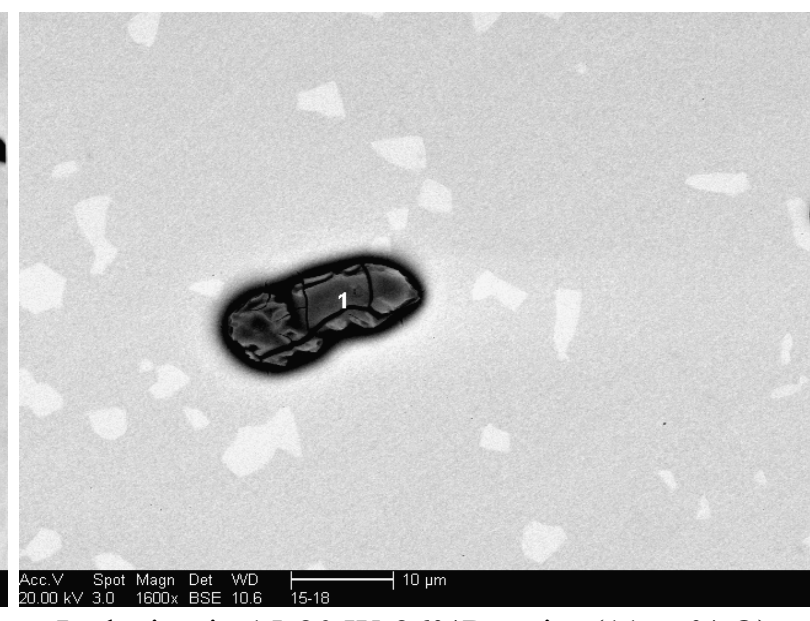

Inclusion in $15-20 \mathrm{~W}-26 \% \operatorname{Re}$ wire $(11 \mathrm{wt} \% \mathrm{O})$

Figure 19. Representative inclusions containing higher $\mathrm{O}$ concentrations.

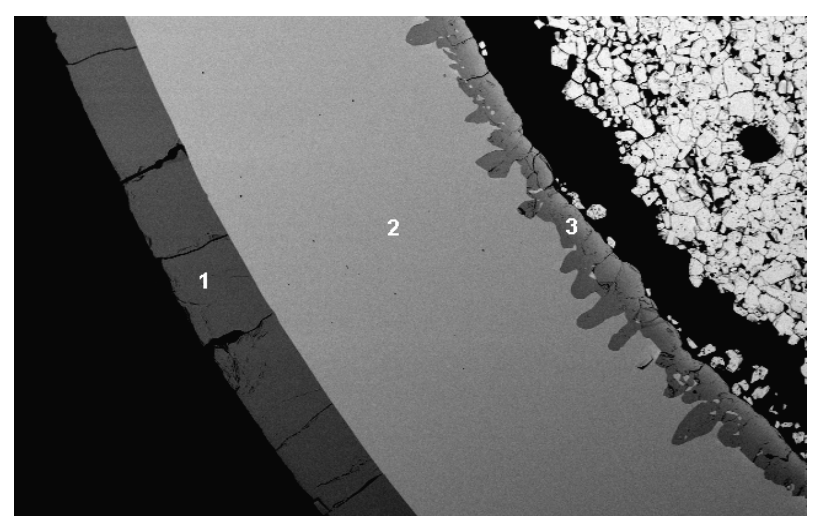

Figure 20. Representative sheath after heating at $1,500{ }^{\circ} \mathrm{C}$ for 3,000 hours.

values indicated by the phase diagram shown in Figure 1. As shown in Figure 21, similar precipitates were observed in three Source A thermocouples, irrespective of heating time. Because these precipitates had not adversely affected Source A thermocouple calibration at 1,000 hours and because their composition and appearance remained similar throughout the test, results suggest that these precipitates would not have affected calibration at later times.

\section{Summary and Recommendations for Future Evaluations}

Results from a long duration test to evaluate Type $\mathrm{C}$ thermocouple drift at $1,500{ }^{\circ} \mathrm{C}$ were adversely affected due to oxygen ingress. Nevertheless, the results do provide some insights about the impact of precipitate formation on thermoelectric response. In particular, post-test examinations indicate that thermocouple signal was not adversely impacted by the precipitates detected after 1,000 hours of heating at $1,500^{\circ} \mathrm{C}$ and suggest that the signal would not have been adversely 


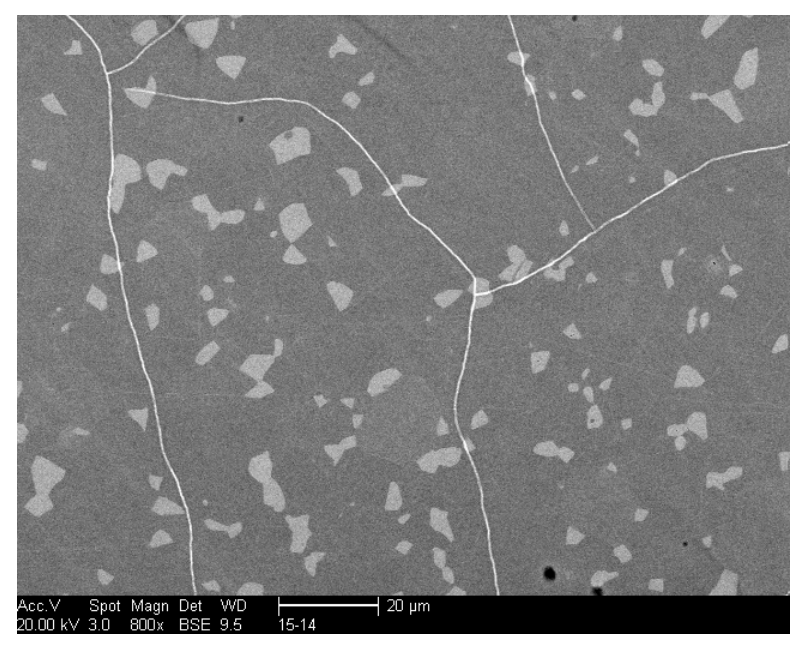

A15-14 (1000 hours)

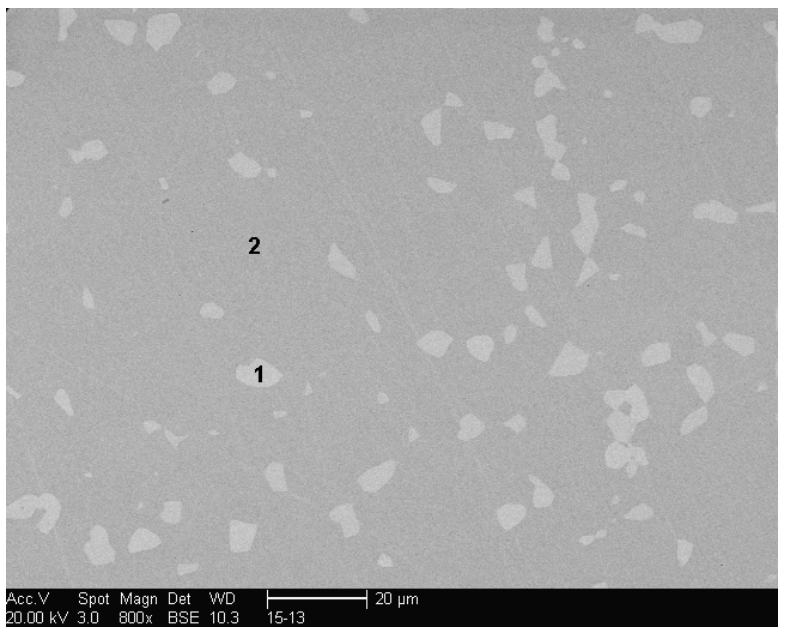

A15-13 (3000 hours)

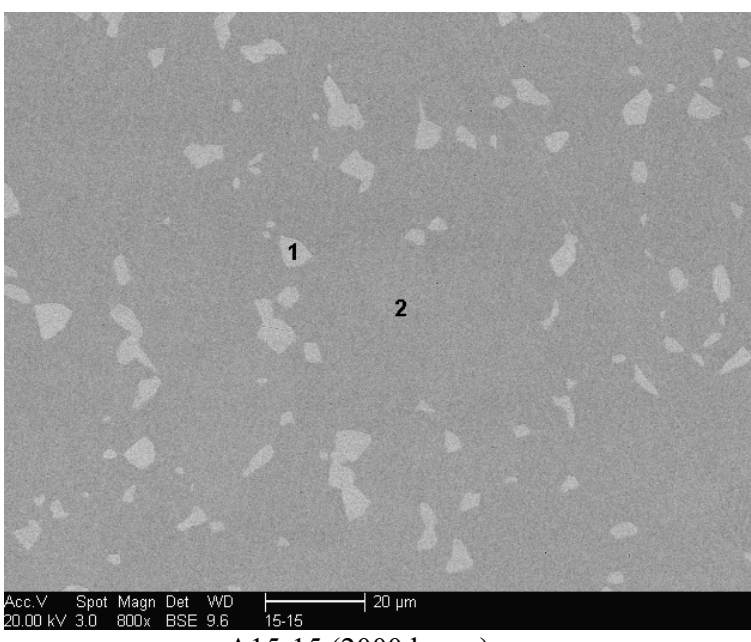

A15-15 (2000 hours)

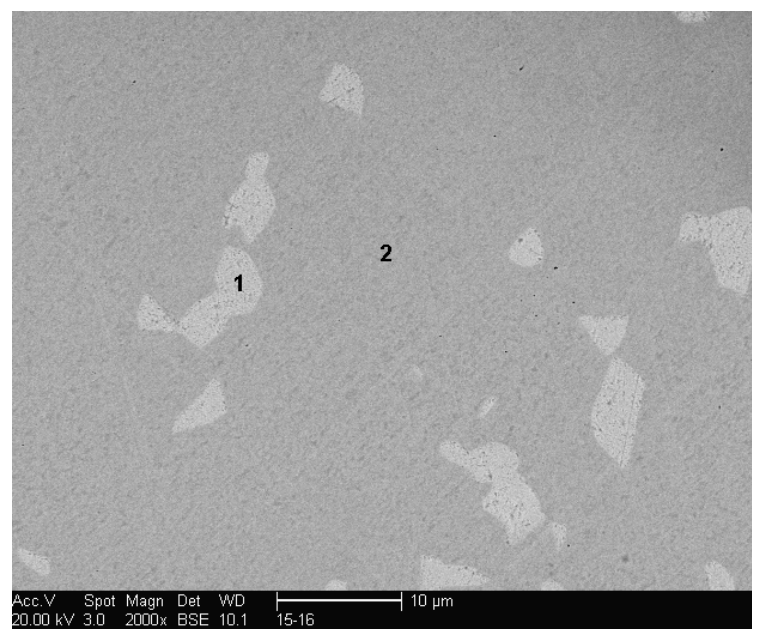

A15-16 (3000 hours)

Figure 21. Comparisons of precipitates observed in Source A W-26\%Re thermocouple wires (magnifications varied).

impacted by these precipitates for longer durations (if oxygen ingress had not occurred in this test).

Post-test examinations indicate that the test results were significantly impacted by oxygen ingress. However, the following observations are of interest.

- Post test examinations indicate consistent degradation irrespective of the thermocouple source (although the vendors producing the wires for these three sources weren't known in all cases, it was known that the wires were acquired from different manufacturers).

- After 2,000 hours, the W-5\%Re thermoelement wires were significantly degraded, appearing porous. SEM examinations detected molybdenum concentrations up to $43 \mathrm{wt} \%$. Oxygen concentrations (away from voids) remained below $2 \mathrm{wt} \%$ in these wires.

- High concentrations of tungsten (up to $70 \mathrm{wt} \%$ ) were detected on the inner surface of the molybdenum thermocouple sheaths after heating for 2,000 hours (in the case of 15-15, the tungsten concentration went from $50 \mathrm{wt} \%$ on the inner surface to less than $2 \mathrm{wt} \%$ in the 
bulk). Rhenium was detected on the outer surface of the sheath, but in lower concentrations (between 0 and $2.3 \mathrm{wt} \%$ ).

- After heating at $1,500{ }^{\circ} \mathrm{C}$ for 3,000 hours, high concentrations of molybdenum were detected throughout the $\mathrm{W}-5 \% \mathrm{Re}$ thermocouple wire and on the porous outer ring of the $\mathrm{W}-26 \% \mathrm{Re}$ wire, irrespective of thermocouple source.

- Particulate formation appearance and composition remains constant, approximately 50$53 \mathrm{wt} \% \mathrm{~W}$ and $43-46 \mathrm{wt} \% \mathrm{Re}$, irrespective of heating duration. Note that this composition is consistent with values indicated by the phase diagram shown in Figure 1.

It is recommended that this test be repeated to observe if similar results are obtained when oxygen ingress doesn't occur. If such a test is repeated, it is also suggested that some of the Type $\mathrm{C}$ thermocouples be heated at temperatures higher than $1500{ }^{\circ} \mathrm{C}$ prior to testing (to observe the impact on precipitate formation and decalibration).

\section{References}

1. R. D. Lanam and D. A. Teonshoff, "An Overview of W-Re Alloys for Temperature Measurement Applications," International Symposium on Rhenium and Rhenium Alloys, February 9-13, 1997, Orlando, Florida.

2. T.B Massalski, H. Okamoto, P. R. Subramanian, and L. Kacprzak, Binary Alloy Phase Diagrams, 2nd Edition, ASM International, 1996.

3. R. L. Shepard and B. H. Montgomery, ORNL Report No. 5108, Oak Ridge, TN, November 1975, pp 418-427.

4. W. E. Browning, Jr., and C. E. Miller, Jr.: Fourth Symposium on Temperature: Its Measurement and Control in Science and Industry, Reinhold Publ. Co., 1962, vol.3, part 2, p. 271.

5. $\quad$ R. P. Pratt, Report No. AERE-M 2081, Harwell, England, March 1968.

6. M. W. Waddell, ORNL Report No. 5108, Oak Ridge, TN, November 1976, pp. 428-431.

7. D.C. Thompson, et al., Report No. BNWL-917, Richland WA, December 1968, pp 431-436.

8. J. D. Heckelman and R. P. Kozar, "Measured Drift of Irradiated and Unirradiated W3\%Re/W25\%Re Thermocouples at a Nominal $2000 \mathrm{~K}$," NASA-TM-X-67818, presented at Fifth Symposium on Temperature, Washington, D.C., June 1971, published in Temperature: Its Measurement and Control in Science and Industry, H. H. Plumb, Ed.-in-Chief (American Institute of Physics, New York, 1972, pp 1935-1949.

9. E. D. Zysk and A. R. Robertson, "Newer Thermocouple Materials," presented at Fifth Symposium on Temperature. Washington, D.C., June 1971, published in Temperature: Its Measurement and Control in Science and Industry, H. H. Plumb, Ed.-in-Chief (American Institute of Physics, New York, 1972, Vol. 4, Part 3, pp. 1697- 1734.

10. R. K. Williams, et al., "Irradiation Induced Precipitation in Tungsten Based, W-Re Alloys," Metallurgical Transactions A, 14A, April 1983, pp 655-666. 
11. G. W. Burns and W. S. Hurst, "An Investigation of W-3\%Re and W-25\%Re Thermoelements in Vacuum, Argon, and Hydrogen,” Report No. NASA CR 72639, Gaithersburg, MD, March 1970.

12. G. W. Burns and W. S. Hurst, "Some Studies on the Behavior of W-Re Thermocouple Materials at High Temperatures,” Report No. NASA CR 72884, NBS, Gaithersburg, MD, February 1972.

13. C. E. Wicks and F. E. Block, Thermodynamic Properties of 65 Elements - Their Oxides, Halides, Carbides, and Nitrides, Bureau of Mines Bulletin 605, 1965.

14. A. Glassner, The Thermochemical Properties of the Oxides, Fluorides, and Chlorides to $2500 \mathrm{~K}$, ANL-5750, 1953. 